\title{
CEO Personal Risk-Taking and Corporate Policies
}

\author{
Matthew D. Cain and Stephen B. McKeon*
}

\begin{abstract}
This study analyzes the relation between chief executive officer (CEO) personal risktaking, corporate risk-taking, and total firm risk. We find evidence that CEOs who possess private pilot licenses (our proxy for personal risk-taking) are associated with riskier firms. Firms led by pilot CEOs have higher equity return volatility, beyond the amount explained by compensation components that financially reward risk-taking. We trace the source of the elevated firm risk to specific corporate policies, including leverage and acquisition activity. Our results suggest that nonpecuniary risk preferences revealed outside the scope of the firm have implications for project selection and various corporate policies.
\end{abstract}

\section{Introduction}

Managerial risk aversion imposes agency costs upon shareholders if managers forego risky, but value-enhancing, projects (Smith and Stulz (1985)). A large literature examines how these risk-related agency costs can be reduced through contracting. For example, if a manager is compensated using convex payoff schemes, then his or her expected wealth is an increasing function of firm risk. This wealth effect should lead to a preference for higher levels of risk, ceteris paribus, mitigating suboptimal project selection. However, factors that affect managerial preferences for risk outside the wealth effect are less clear.

There is a burgeoning literature studying the relation among managerial attributes, personal psychology, and economic outcomes. However, an individual's

*Cain, mdcain@outlook.com, U.S. Securities and Exchange Commission, Washington, DC 20549; McKeon (corresponding author), smckeon@uoregon.edu, University of Oregon, Lundquist College of Business, Eugene, OR 97403. We thank an anonymous referee, David Cesarini, Shane Corwin, Henrik Cronqvist, Cláudia Custódio, Diane Del Guercio, Dave Denis, Paul Gao, Ro Gutierrez, Jarrad Harford (the editor), Campbell Harvey, David Haushalter, Byoung-Hyoun Hwang, Lee Kitzenberg, Matti Keloharju, Tobias Muhlhofer, Mark Reinecke, Stephan Siegel, Scott Yonker, Marvin Zuckerman, seminar participants at Notre Dame, and participants at the 2010 State of Indiana Conference, the 2011 Northern Finance Association Conference, the 2012 UniSA Behavioral Finance and Capital Markets Conference, the 2011 Miami Behavioral Finance Conference, and the 2012 Citation Jet Pilots Convention for helpful comments. The U.S. Securities and Exchange Commission (SEC), as a matter of policy, disclaims responsibility for any private publication or statement by any of its employees. The views expressed herein are those of the author and do not necessarily reflect the views of the SEC or of the author's colleagues upon the staff of the SEC. 
preference for bearing risk, one of the most fundamental personal characteristics of interest to economists, is difficult to measure empirically, and represents a gap in our understanding of the determinants of managerial risk-taking. In this paper, we measure chief executive officers' (CEOs') revealed preferences for risk-taking by observing their activities outside the scope of the firm, and we examine the policy implications for the firms they lead.

We measure personal risk-taking using a novel data set of CEOs who hold aircraft pilot licenses. To our knowledge, this is the first study that attempts to measure and analyze personal risk-taking at the individual CEO level. We begin by documenting that operating small aircraft exposes the individual to a greater level of health risk, especially the type of flying undertaken by CEOs who hold airmen certificates. We test whether firms managed by risk-taking CEOs exhibit policies and attributes that are consistent with their CEOs' revealed personal preferences.

Cronqvist, Makhija, and Yonker (2012) document a positive correlation between CEO personal and professional leverage, suggesting that CEOs make consistent decisions when faced with similar economic choices in different domains. Importantly, our proxy for risk-taking is nonpecuniary; in other words, our focus is on the risk-aversion effect rather than the wealth effect. ${ }^{1}$ Thus, our study extends prior work by examining consistency not only across domains (personal/ professional), but also across risk types (health/financial).

Prior studies have documented that the desire to fly an airplane represents one of the highest predictors of the thrill- and adventure-seeking component of sensation-seeking personalities (Zuckerman (1971)). Sensation seeking is a genetic personality trait that is correlated with a propensity toward risk-taking behavior in an extraordinarily wide range of different settings, such as driving, sexual activity, sports, and vocation, among others (Zuckerman (2007)). Furthermore, Grinblatt and Keloharju (2009) examine the sensation-seeking trait in retail investors and find that it is associated with economically meaningful variation in stock trading behavior. Taken together, these studies suggest that a CEO's risk-taking behavior in noneconomic contexts could plausibly contain information about the CEO's corporate policy choices that impact firm risk.

Using a sample of 15,627 firm-years between 1992 and 2009, 1,016 of which are led by pilot CEOs, we test for differences in corporate policies, such as leverage and acquisitiveness, and relate these policy choices to overall firm risk. We find that pilot CEOs are associated with elevated levels of leverage in the firms they lead, consistent with more pronounced corporate risk-taking. However, when we subsequently analyze the effect of pilot CEOs on overall firm risk, our personal risk-taking proxy contains explanatory power for stock return volatility even after controlling for leverage and compensation structure. These results indicate that the influence of CEO personal risk tolerance on corporate risk-taking extends beyond the wealth effect related to compensation incentives.

In order for a CEO's personal preferences to affect firm risk through a particular channel, it must be the case that the CEO exerts considerable influence over

\footnotetext{
${ }^{1}$ This terminology is first used by Guay (1999) to describe the two components that determine the effect of firm risk on managerial preferences. We defer a more detailed explanation of the two effects to Section II.B.
} 
the policy in question. In a recent study, Graham, Harvey, and Puri (2015) report that CEOs dominate merger and acquisition (M\&A) decisions relative to other types of corporate decisions. Acquisitions are particularly interesting in this context because they are a window into CEO project selection. Thus, if managerial risk aversion imposes agency costs through suboptimal project selection, and our proxy identifies variation in risk aversion, then acquisition activity is a plausible channel in which we could find systematic differences.

Consistent with our hypothesis, we find that pilot CEOs are significantly more acquisitive. More importantly, we find that a substantial amount of the increase in return volatility is explained by the acquisition activity of the firms led by pilot CEOs. This is particularly interesting in light of the evidence reported by Amihud and Lev (1981) suggesting that risk reduction is a plausible motive for acquisition activity. In our sample, M\&A activity is associated with lower firm risk on average, as predicted by Amihud and Lev, but M\&A activity led by pilot CEOs tends to increase firm risk. This implies that in addition to polices that prior studies have shown to affect firm risk, such as research and development (R\&D), leverage, and compensation convexity, acquisition activity is an important channel through which risk-taking CEOs can increase the riskiness of their firms.

We examine acquisition announcement returns to investigate the impact of risk-taking CEOs on shareholder value. If our proxy represents overconfident or risk-seeking CEOs, it is plausible that their acquisitions are value destroying, as noted by Malmendier and Tate (2008). In the full sample, we do not find evidence of value destruction. Furthermore, when we isolate those firms with high bookto-market ratios (also known as value firms), we find that acquirers led by pilot CEOs have significantly higher announcement returns. Although we stop short of classifying our proxy as universally good or bad, the evidence suggests that project selection through acquisition is materially improved within those firms that have few organic investment opportunities.

Our final set of tests analyzes the relation between our proxy for personal risk-taking and compensation contracts that reward risk-taking. Consistent with theoretical predictions, we find that pilot CEOs are associated with compensation structures that are more sensitive to changes in equity volatility and that these CEOs are more likely to have high performance-based pay. However, we note that interpretation of these results is challenging because although providing incentive compensation to a more risk-tolerant agent is less costly, the misalignment with risk-neutral shareholders is also less pronounced. Sorting out the determinants of this bilateral choice will be a topic for future research.

Our results are robust to a variety of alternative explanations. Many of our specifications employ firm, industry, geographical, and/or year fixed effects and find no qualitative differences in the conclusions. In addition, we also perform robustness checks that control for a variety of other managerial characteristics that can influence financial decision making, such as common proxies for overconfidence, upbringing in the Great Depression era, military experience, tenure, and age. We demonstrate that pilot CEOs primarily fly as a hobby, rather than as a business necessity, confirming that we are measuring personal risk-taking preferences rather than behavior driven by circumstance. We also note that if our risk-taking measure is spuriously correlated with ability or other unobservable 
factors of superior skill, we would expect these CEOs to have higher total compensation, yet we find no significant differences along these lines.

Ultimately, piloting is only one of numerous outlets that individuals with a propensity toward risk-taking may pursue; our proxy thus has a certain degree of noise. To the extent that we find a significant relation between our proxy for personal risk-taking behavior, corporate policies, and overall firm risk despite this noise, the results lend credence to the consideration of personal risk-taking in corporate finance.

Our primary contributions can be summarized as follows: i) We identify a characteristic, personal risk-taking, that is both observable ex ante and positively correlated with risk preferences in CEOs. ii) Our proxy has explanatory power for equity return volatility after controlling for compensation structure, suggesting that the CEO risk-aversion effect is a nontrivial determinant of overall firm risk. iii) We document that elevated firm risk is delivered through M\&A policy in our sample, consistent with the mitigation of agency costs related to project selection.

The remainder of the paper is organized as follows: Section II develops our hypothesis and outlines the testable predictions. Section III explains the datacollection process, and Section IV presents our empirical results. Section V concludes.

\section{Hypothesis Development}

Recent empirical work in finance indicates that managers behave consistently in their personal and professional lives (Chyz (2013), Cronqvist et al. (2012)). In this study, we examine consistency in risk preferences using the piloting of small aircraft as a proxy for personal risk-taking. Our main hypothesis is that a CEO's revealed preference for bearing nonpecuniary (health) risk is correlated with corporate risk-taking in the firm the CEO leads. In this section, we establish the use of pilot licenses as a proxy for personal risk-taking and review the extant literature that supports the main hypothesis and testable predictions.

\section{A. Piloting and Health Risk}

The first piece of empirical evidence that piloting small aircraft is consistent with elevated levels of health risk is provided by the life insurance industry, which is in the business of assessing mortality risk. A Society of Actuaries study (McFall (1992)) examines the effects on mortality from piloting small aircraft, focusing narrowly on civilian aviators not flying for pay, the precise category into which most pilot CEOs fall. McFall reports that the mortality rate of this group increases over $100 \%$ for a 40 -year-old male who qualifies for standard (averagelife-expectancy) policies. Mortality rates increase over $200 \%$ for individuals who otherwise qualify for substandard (high-risk) policies. The report specifically singles out business executives as pilots who are especially high risk. Searches of the popular press reveal many examples of CEOs who have lost their lives piloting small aircraft. ${ }^{2}$

\footnotetext{
${ }^{2}$ Some examples include Steven Appleton, CEO of Micron (2012); Daniel Dorsch, former CEO of Checkers Drive-In Restaurants, Inc. (2009); Douglas J. Sharratt, CEO of ProSoft Technologies
} 
To further highlight the riskiness of flying small aircraft, we compare fatality rates for general aviation pilots to fatality rates associated with a variety of other activities. We obtain fatality data primarily from the National Transportation Safety Board for alternative forms of flying and the National Highway Traffic Safety Administration for operating motorcycles and passenger cars. ${ }^{3}$ Figure 1 plots fatality rates over the past decade for (i) personal/business flying, (ii) motorcycles, (iii) hot-air balloons, (iv) personal helicopters, (v) crop dusters,

\section{FIGURE 1}

\section{Fatal Crash Rates per Million Hours of Various Forms of Transportation}

Data sources are as follows:

- Personal/business flying, corporate/executive aircraft, aerial application aircraft: National Transportation and Safety Board Annual Review of Aircraft Accident Data, U.S. General Aviation, Calendar Year 2005; General Aviation and Air Taxi Activity and Avionics Surveys CY2005, Table 1.6. Corporate/executive aircraft category includes a paid, professional flight crew, whereas personal/business flying does not.

- Motorcycle, passenger cars: National Highway Traffic Safety Administration (NHTSA), Fatality Analysis Reporting System Encyclopedia. To convert miles driven to hours driven, we assume an average speed of 55 miles per hour.

- Hot-air balloons: National Transportation and Safety Board Annual Review of Aircraft Accident Data, U.S. General Aviation, "Lighter-than-air" craft category.

- Helicopter (personal, business): 2009 Nall Report, An AOPA Air Safety Foundation Publication.

- Commercial airlines: National Transportation and Safety Board, Aviation Accident Statistics, Table 6.

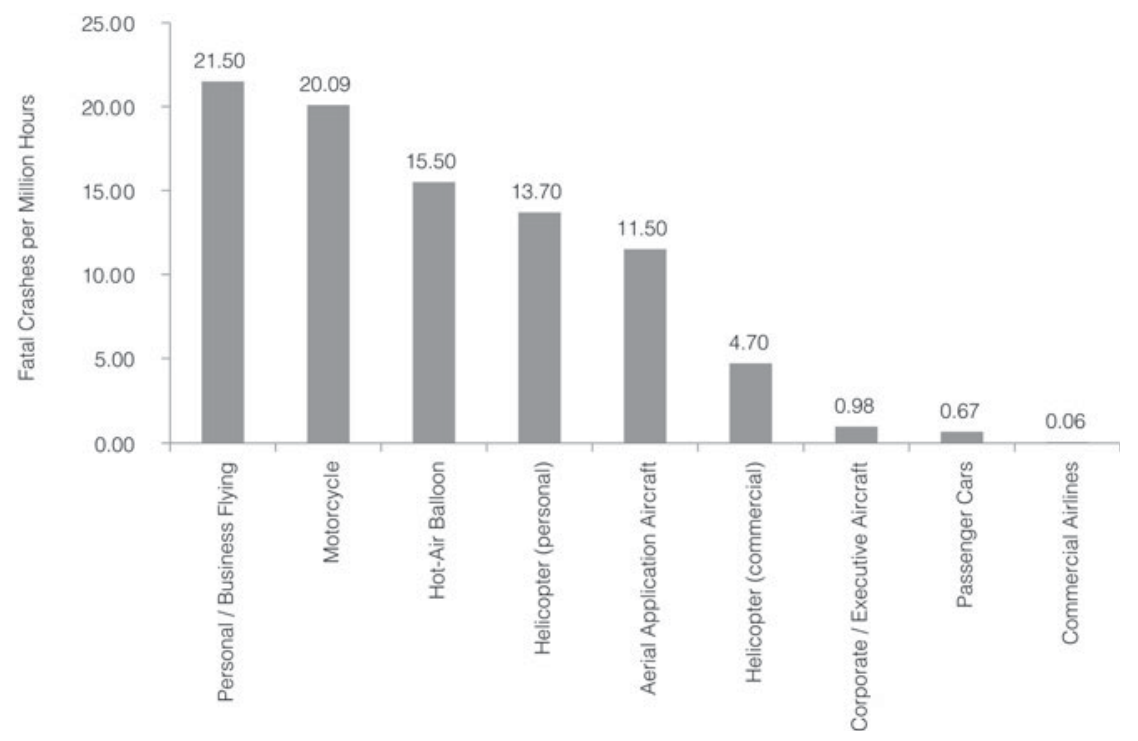

(2008); Jeanette Symons, CEO of Industrious Kid, Inc. (2008); Bruce R. Kennedy, former CEO of Alaska Airlines (2007); Michael F. Wille, CEO of The Title Company, Inc. (2006); David R. Burke, Sr., CEO of CeleXx Corp. (2001); Michael A. Chowdry, CEO of Atlas Air, Inc. (2001); and J. Wesley Rogers, CEO of Oceaneering International, Inc. (1986).

${ }^{3}$ One challenge in comparing the data is that flying data are reported on a per-hour basis, whereas driving data are reported per mile; thus, an assumption about the average speed of automobile traffic is required to convert the data to fatalities per hour. We assume an average speed of 55 miles per hour, which we consider to be a conservatively high figure. Lower speed assumptions would result in driving fatality rates that are lower than those reported. 
(vi) commercial helicopters, (vii) corporate/executive flying, (viii) passenger cars, and (ix) commercial airlines. Most pilot CEOs fall into category (i). The term business flying in category (i) is defined as "flights made in furtherance of the pilot's own livelihood or in support of business endeavors," whereas executives riding on a plane with a professional crew fall into category (vii). The data indicate that the latter form of travel is not much different than driving passenger cars in terms of the risk of mortality, and flying on commercial airlines is even safer. However, operating small aircraft is substantially more dangerous. At 21.5 fatalities per million hours, personal/business flying is over 30 times more dangerous than driving and ranks as the most dangerous activity among the nine forms analyzed, well ahead of even crop dusting. Taken together, the life insurance and fatality analyses suggest that operating small aircraft is indeed a very risky activity. These results offer empirical support for our claim that hobby pilots are engaging in risk-taking behavior and that our pilot variable is therefore a valid proxy for health risk preferences.

\section{B. Testable Predictions}

Because we use a source of variation in risk tolerance that is nonpecuniary, our research design allows us to test novel aspects of the relation between risk preferences and corporate risk-taking. As shown by Pratt (1964), Smith and Stulz (1985), and Guay (1999), a CEO's utility is affected by changes in firm risk in two ways: a wealth effect and a risk aversion effect. Option compensation creates convex payoffs for the manager, and compensation convexity (vega) measures what Guay refers to as the wealth effect. The wealth effect captures the notion that utility increases when firm risk increases because expected wealth increases simultaneously. The offsetting effect on utility is the risk-aversion effect. For a risk-averse CEO, utility is negatively affected by increases in firm risk because the CEO possesses firm-specific human capital and/or holds an undiversified portfolio. A large literature examines the relation between the wealth effect and corporate risk-taking, but our proxy for personal risk-taking allows us to control for the wealth effect while focusing our tests on variation in the risk-aversion effect. ${ }^{4}$

The main testable prediction of our hypothesis is that pilot CEOs will be positively associated with overall firm risk. Our empirical tests measure overall firm risk using equity return volatility. Firms with high return volatility are "riskier" than firms with low return volatility; thus, we expect the indicator variable for pilot CEOs to load positively in regressions that explain volatility.

If our proxy identifies CEOs who are less prone to agency problems related to risk aversion, then these CEOs should accept risky projects with higher frequency. Therefore, we predict that our proxy will be associated with higher levels of acquisition activity. This prediction is also consistent with the literature on sensation seeking, a trait that endows the CEO with an elevated propensity for

\footnotetext{
${ }^{4}$ See, for example, Guay (1999), Coles, Daniel, and Naveen (2006), Low (2009), and Chava and Purnanandam (2010).
} 
engaging in financial transactions, similar to the results for the trading activity of individual investors.

The theoretical prediction as to whether or not increased acquisition activity impacts firm risk is ambiguous. If acquisitions are diversifying, firm risk could decrease (Amihud and Lev (1981)). Alternatively, a low-beta firm acquiring a high-beta firm could increase the volatility of returns to equity. We empirically test whether the type of acquisitions made by pilot-led firms is associated with changes in the overall risk profile of the firm.

\section{Data}

We draw the initial sample of CEOs from the Compustat Executive Compensation (ExecuComp) database, which primarily covers firms in the Standard \& Poor's (S\&P) 1500 Index. Because ExecuComp coverage begins around 1992, we include CEOs in the sample only if the ExecuComp "Became CEO" date is on or after Jan. 1, 1991. This mitigates any survival bias that could affect CEOs included in the data set. This first pass produces 4,012 CEO-firm combinations. We then search for CEO names on the Federal Aviation Administration's (FAA's) Airmen Certification database. ${ }^{5}$ If a given name does not produce a match in the FAA's database, then this observation is coded as a nonpilot and no further validation is necessary.

If a given name produces at least one name match in the FAA's database, we take further steps to confirm whether the pilot certificate belongs to the sample CEO. We use LexisNexis, Bloomberg, and public records searches to obtain birth dates, home addresses, and other personal information on the CEOs that can be used to validate the FAA certificate information. Doing so eliminates falsepositive name matching and reassigns those observations into the nonpilot group. We are able to locate sufficient personal information to confidently accept or reject the FAA name matches for over $77 \%$ of the initial sample. The manual data checking results in a final sample of 179 pilot CEOs and 2,931 CEO nonpilots. During the sample period, 11 of the pilot CEOs worked for more than one company, and 12 firms employed more than one pilot as CEO. In total, the full panel covers 1,016 CEO-pilot firm-years and 14,611 CEO-nonpilot firm-years.

Panel A of Table 1 reports descriptive statistics on the airmen certificates linked to the sample CEOs. The vast majority fall under the Private Pilot designation, which is the level of certification required to solo pilot an aircraft under $12,500 \mathrm{lbs}$. Another $16 \%$ and $7.3 \%$ further reach the Commercial Pilot and Airline Transport Pilot (ATP) certifications, respectively, which require more rigorous examination and training.

The pilot CEOs hold a variety of ratings that provide additional flight privileges. For example, about half the pilots hold an instrument rating, allowing them to fly under conditions in which view is obstructed. Furthermore, the pilots

\footnotetext{
${ }^{5}$ Available at https://amsrvs.registry.faa.gov/airmeninquiry/. The FAA Web site also provides a downloadable database of active airmen certificate information. We search the online registry in order to locate both current and expired certificates. This database is separate from the FAA's civil aircraft registry utilized by Yermack (2006).
} 
TABLE 1

\section{Variable Descriptive Statistics}

Panel A of Table 1 reports descriptive statistics for the pilot CEOs, Panel B reports descriptive statistics for the sample firm-year observations, and Panel C reports pair-wise variable correlations, with * denoting correlations significant at the $5 \%$ level or greater. The sample contains 179 pilot CEOs, and Panel A reports the proficiency levels attained by pilot CEOs and aircraft certificate ratings. These levels and ratings are not mutually exclusive (i.e., CEOs may hold multiple certificates and ratings). Airmen certificate information is obtained from the FAA's Airmen Certification database (https://amsrvs.registry.faa.gov/airmeninquiry/), which includes both active and inactive certificates. All variables are defined in the Appendix.

Panel A. CEO Pilot Descriptive Statistics

\begin{tabular}{l}
\multicolumn{1}{c}{ Pilot Certificates } \\
\hline Airline transport pilot \\
Commercial pilot \\
Private pilot \\
Student pilot \\
Flight instructor \\
Ground instructor \\
No certificate attained
\end{tabular}

\begin{tabular}{r}
$N$ \\
\hline 13 \\
29 \\
118 \\
14 \\
5 \\
9 \\
4
\end{tabular}

\begin{tabular}{l} 
Certificate Ratings \\
\hline Single-engine airplane \\
Instrument rating \\
Multiengine airplane \\
Helicopter \\
Water landing \\
Glider \\
Hot-air balloon \\
Experimental aircraft
\end{tabular}

No. of CEOs

\begin{tabular}{|c|c|c|c|}
\hline \multicolumn{2}{|c|}{ Yes } & \multicolumn{2}{|c|}{ No } \\
\hline$N$ & $\%$ & $N$ & $\%$ \\
\hline 179 & $5.8 \%$ & 2,931 & $94.2 \%$ \\
\hline 304 & $8.1 \%$ & 3,470 & $91.9 \%$ \\
\hline
\end{tabular}

$\begin{array}{lc}\text { Military experience } & 304 \\ \text { Panel B. Sample Firm-Year Descriptive Statistics }\end{array}$

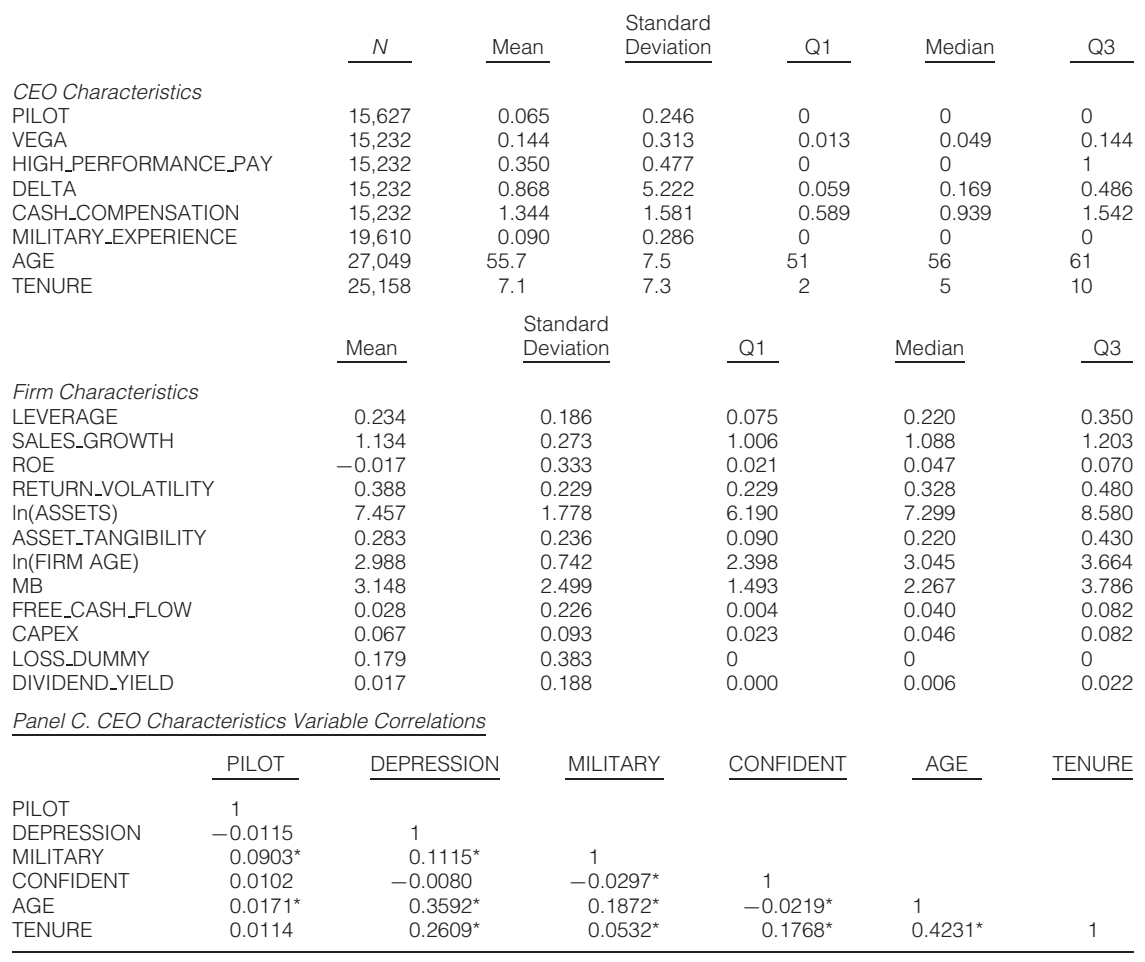

in our sample hold a diverse range of class ratings that allow them to operate multiple-engine airplanes (55 CEOs), helicopters (10), gliders (4), experimental 
aircraft (3), hot-air balloons, (3) and planes that land on water (10). Panel B of Table 1 reports descriptive statistics for sample CEO characteristics: military experience, age, and tenure at the firm. Firm-level descriptive statistics are reported for variables that enter later models. All variables are defined in the Appendix.

Panel C of Table 1 reports pair-wise correlation coefficients for a wider range of CEO characteristics variables that have been used in prior studies, with an asterisk denoting statistical significance at the 5\% level or better. Neither overconfidence nor Depression-era upbringing is significantly correlated with the PILOT variable; thus, we exclude these variables in subsequent tests. ${ }^{6}$ PILOT is positively correlated with MILITARY, which provides some independent corroboration of the validity of the proxy. Those with a military background may have developed an increased tolerance of risk during their time in service, or this trait may be innate to those individuals who elect to join the military. We thus control for military service in the following models, although we are unable to differentiate between imprinting through combat exposure versus a selection effect. We also note that $100 \%$ of the sample pilot CEOs are male; thus, the following empirical tests are not directly related to the prior literature on CEO gender.

Table 2 provides statistics on the distribution of firms by industry and urban/ rural classification. One concern in using pilot license data as a proxy for sensation seeking is that if sample firms are disproportionally located in rural locales, the choice to obtain a pilot's license may be driven by a lack of alternative options for air travel. To address this possibility, we collect geographical data on firm headquarters and the corresponding Metropolitan Statistical Area (MSA) as defined by the U.S. Census Bureau. ${ }^{7}$ Panel A reports the most common MSAs for pilot CEO firms. The 20 most common MSAs, all of which have international airports, account for nearly $70 \%$ of all observations. Furthermore, 150 of the 170 firms fall within an MSA ranked in the top 100 by population, which corresponds to at least half a million people. Of the 20 that do not, 10 are ranked between 100 and 150, and 2 are foreign, leaving only 8 firms that could be considered rural. In results reported in the Internet Appendix (available at www.jfqa.org), we test whether the proportion of pilot CEOs who live near commercial airports differs from the general population of CEOs; we find it does not. Moreover, because half of the sample pilots do not hold an instrument rating, they would not be permitted to fly the significant distances that would be required for typical business travel. ${ }^{8}$ Thus, the pilot CEOs in the sample generally appear to pursue flying as a hobby and not as a business necessity. For robustness, we reestimate all empirical tests with MSA fixed effects to control for the possibility that geographical differences influence the findings and obtain qualitatively similar results. These results are reported in the Internet Appendix.

Panel B of Table 2 reports descriptive statistics on the industries of firms headed by CEO pilots by 2-digit Standard Industrial Classification (SIC) codes.

\footnotetext{
${ }^{6}$ For robustness, we reestimate all models with the overconfidence and Depression-era upbringing variables included. All of the results are qualitatively similar.

${ }^{7}$ MSA data are available at http://www.census.gov

${ }^{8}$ We thank Tobias Muhlhofer for bringing this to our attention.
} 
TABLE 2

Pilot-CEO Sample Location and Industry Distribution

Panel A of Table 2 reports the location distribution of firm headquarters for the pilot-CEO sample, by MSA. Panel B reports the industry distribution of the sample, by 2-digit SIC (SIC2) codes.

Panel A. Pilot Firm Locations

\begin{tabular}{|c|c|c|c|}
\hline MSA\# & $N$ & $\%$ & MSA Description \\
\hline 41940 & 17 & $10.0 \%$ & San Jose-Sunnyvale-Santa Clara, CA \\
\hline 35620 & 16 & $9.4 \%$ & New York-Northern New Jersey-Long Island, NY-NJ-PA \\
\hline 26420 & 10 & $5.9 \%$ & Houston-Sugar Land-Baytown, TX \\
\hline 33460 & 10 & $5.9 \%$ & Minneapolis-St. Paul-Bloomington, MN-WI \\
\hline 16980 & 9 & $5.3 \%$ & Chicago-Naperville-Joliet, IL-IN-WI \\
\hline 19100 & 8 & $4.7 \%$ & Dallas-Fort Worth-Arlington, TX \\
\hline 31100 & 7 & $4.1 \%$ & Los Angeles-Long Beach-Santa Ana, CA \\
\hline 14460 & 6 & $3.5 \%$ & Boston-Cambridge-Quincy, MA-NH \\
\hline 41860 & 5 & $2.9 \%$ & San Francisco-Oakland-Fremont, CA \\
\hline 41180 & 4 & $2.4 \%$ & St. Louis, MO-IL \\
\hline 47900 & 4 & $2.4 \%$ & Washington-Arlington-Alexandria, DC-VA-MD-WV \\
\hline 12060 & 3 & $1.8 \%$ & Atlanta-Sandy Springs-Marietta, GA \\
\hline 17460 & 3 & $1.8 \%$ & Cleveland-Elyria-Mentor, $\mathrm{OH}$ \\
\hline 17140 & 2 & $1.2 \%$ & Cincinnati-Middletown, $\mathrm{OH}-\mathrm{KY}-\mathrm{IN}$ \\
\hline 19740 & 2 & $1.2 \%$ & Denver-Aurora, CO \\
\hline 29820 & 2 & $1.2 \%$ & Las Vegas-Paradise, NV \\
\hline 37980 & 2 & $1.2 \%$ & Nashville-Davidson-Murfreesboro-Franklin, TN \\
\hline 38900 & 2 & $1.2 \%$ & Portland-Vancouver-Beaverton, OR-WA \\
\hline 41700 & 2 & $1.2 \%$ & San Antonio, TX \\
\hline 41740 & 2 & $1.2 \%$ & San Diego-Carlsbad-San Marcos, CA \\
\hline \multicolumn{4}{|c|}{ Panel B. Pilot Firm Industries } \\
\hline $\mathrm{SIC2}$ & $\underline{N}$ & $\%$ & SIC Description \\
\hline 73 & 18 & $10.6 \%$ & Business services \\
\hline 36 & 13 & $7.6 \%$ & Electronic equipment and components, except computer equipment \\
\hline 35 & 11 & $6.5 \%$ & Industrial and commercial machinery and computer equipment \\
\hline 49 & 11 & $6.5 \%$ & Electric, gas, and sanitary services \\
\hline 20 & 10 & $5.9 \%$ & Food and kindred products \\
\hline 37 & 10 & $5.9 \%$ & Transportation equipment \\
\hline 38 & 8 & $4.7 \%$ & Instruments and related products \\
\hline 33 & 7 & $4.1 \%$ & Primary metal industries \\
\hline 28 & 6 & $3.5 \%$ & Chemicals and allied products \\
\hline 60 & 6 & $3.5 \%$ & Depository institutions \\
\hline 80 & 6 & $3.5 \%$ & Health services \\
\hline 29 & 5 & $2.9 \%$ & Petroleum and coal products \\
\hline 48 & 5 & $2.9 \%$ & Communications \\
\hline 13 & 4 & $2.4 \%$ & Oil and gas extraction \\
\hline 39 & 4 & $2.4 \%$ & Miscellaneous manufacturing industries \\
\hline 87 & 4 & $2.4 \%$ & Engineering and management services \\
\hline
\end{tabular}

The pilot CEOs lead firms in a diverse range of industries. The two most prevalent SIC codes are business services (10.6\%) and electronic equipment (7.6\%), followed by industries such as machinery, utilities, and food products. It does not appear that firms with pilot CEOs are disproportionately located in aviationrelated industries or that any single industry dominates the sample. Nonetheless, to control for the possibility that industry characteristics affect the results in later sections, we employ industry fixed effects in some models.

\section{Empirical Results}

\section{A. Behavioral Consistency in Risk Attitudes}

In Table 3 we explore the link between CEO personal risk-taking and overall firm risk. Following Guay (1999) and others, our dependent variable is the riskiness of a firm's projects, measured as the annualized standard deviation of 


\section{TABLE 3}

Pilot CEOs and Firm Risk

\begin{tabular}{|c|c|c|c|c|c|c|}
\hline Independent Variables & 1 & 2 & 3 & 4 & 5 & 6 \\
\hline \multicolumn{7}{|c|}{ Panel A. CEO Characteristics } \\
\hline PILOT & & $\begin{array}{l}0.022^{\star \star \star} \\
(0.007)\end{array}$ & $\begin{array}{c}0.022^{\star \star} \\
(0.038)\end{array}$ & $\begin{array}{c}0.029^{\star \star} \\
(0.016)\end{array}$ & $\begin{array}{l}0.032^{\star \star \star} \\
(0.002)\end{array}$ & $\begin{array}{c}0.035^{\star \star} \\
(0.014)\end{array}$ \\
\hline MILITARY & & & & $\begin{array}{c}-0.013 \\
(0.174)\end{array}$ & $\begin{array}{c}-0.014 \\
(0.103)\end{array}$ & $\begin{array}{c}-0.013 \\
(0.426)\end{array}$ \\
\hline AGE_40-49 & & & & $\begin{array}{c}-0.064^{* * *} \\
(0.003)\end{array}$ & $\begin{array}{c}-0.062^{\star \star \star} \\
(0.003)\end{array}$ & $\begin{array}{c}-0.048^{* *} \\
(0.042)\end{array}$ \\
\hline AGE_50-59 & & & & $\begin{array}{c}-0.084^{\star * *} \\
(0.000)\end{array}$ & $\begin{array}{c}-0.074^{\star \star \star} \\
(0.000)\end{array}$ & $\begin{array}{c}-0.053^{\star \star} \\
(0.036)\end{array}$ \\
\hline$A G E \geq 60$ & & & & $\begin{array}{c}-0.079^{* * *} \\
(0.000)\end{array}$ & $\begin{array}{c}-0.070^{\star \star \star} \\
(0.001)\end{array}$ & $\begin{array}{c}-0.053^{* *} \\
(0.041)\end{array}$ \\
\hline In(TENURE) & & & & $\begin{array}{c}-0.012^{\star \star \star} \\
(0.001)\end{array}$ & $\begin{array}{c}-0.009^{\star \star \star} \\
(0.004)\end{array}$ & $\begin{array}{c}-0.004 \\
(0.264)\end{array}$ \\
\hline VEGA & $\begin{array}{c}-0.002 \\
(0.856)\end{array}$ & $\begin{array}{c}-0.011 \\
(0.222)\end{array}$ & $\begin{array}{c}-0.035^{\star \star \star} \\
(0.000)\end{array}$ & $\begin{array}{c}-0.039^{* * *} \\
(0.001)\end{array}$ & $\begin{array}{c}-0.039^{\star \star \star} \\
(0.000)\end{array}$ & $\begin{array}{c}-0.032^{\star \star \star} \\
(0.008)\end{array}$ \\
\hline DELTA & $\begin{array}{l}0.031^{* * *} \\
(0.000)\end{array}$ & $\begin{array}{l}0.037^{\star \star \star} \\
(0.000)\end{array}$ & $\begin{array}{l}0.017^{\star \star \star} \\
(0.000)\end{array}$ & $\begin{array}{l}0.025^{\star * *} \\
(0.000)\end{array}$ & $\begin{array}{l}0.020^{\star \star \star} \\
(0.000)\end{array}$ & $\begin{array}{l}0.018^{\text {*** }} \\
(0.002)\end{array}$ \\
\hline \multicolumn{7}{|c|}{ Panel B. Firm Characteristics } \\
\hline In(ASSETS) & $\begin{array}{c}-0.053^{\star \star \star} \\
(0.000)\end{array}$ & $\begin{array}{c}-0.054^{\star \star \star} \\
(0.000)\end{array}$ & $\begin{array}{c}-0.044^{\star \star \star} \\
(0.000)\end{array}$ & $\begin{array}{c}-0.042^{\star \star *} \\
(0.000)\end{array}$ & 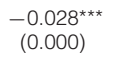 & $\begin{array}{c}0.004 \\
(0.674)\end{array}$ \\
\hline LEVERAGE & $\begin{array}{l}0.069^{* \star *} \\
(0.000)\end{array}$ & $\begin{array}{l}0.072^{\star \star \star} \\
(0.000)\end{array}$ & $\begin{array}{l}0.127^{\star \star \star} \\
(0.000)\end{array}$ & $\begin{array}{l}0.135^{\star * *} \\
(0.000)\end{array}$ & $\begin{array}{l}0.077^{\star \star \star} \\
(0.000)\end{array}$ & $\begin{array}{l}0.071^{* *} \\
(0.050)\end{array}$ \\
\hline R\&D & & & & & $\begin{array}{l}0.463^{\star \star \star} \\
(0.000)\end{array}$ & $\begin{array}{c}-0.055 \\
(0.661)\end{array}$ \\
\hline SALES_GROWTH & & & & & $\begin{array}{l}0.043^{\star \star \star} \\
(0.000)\end{array}$ & $\begin{array}{c}0.010 \\
(0.318)\end{array}$ \\
\hline ROE & & & & & $\begin{array}{c}-0.158^{\star \star \star} \\
(0.000)\end{array}$ & $\begin{array}{c}-0.124^{\star \star \star} \\
(0.000)\end{array}$ \\
\hline MB & & & & & $\begin{array}{c}-0.002 \\
(0.456)\end{array}$ & $\begin{array}{l}0.010^{* \star} \\
(0.019)\end{array}$ \\
\hline In(FIRM AGE) & & & & & $\begin{array}{c}-0.031^{\star \star \star} \\
(0.000)\end{array}$ & $\begin{array}{c}-0.149^{\star \star \star} \\
(0.000)\end{array}$ \\
\hline Fixed effects & None & None & $\begin{array}{l}\text { Industry, } \\
\text { Year }\end{array}$ & $\begin{array}{l}\text { Industry, } \\
\text { Year }\end{array}$ & $\begin{array}{l}\text { Industry, } \\
\text { Year }\end{array}$ & $\begin{array}{l}\text { Firm, } \\
\text { Year }\end{array}$ \\
\hline $\begin{array}{l}\text { No. of obs. } \\
\text { No. of firms }\end{array}$ & $\begin{array}{r}14,773 \\
2,208\end{array}$ & $\begin{array}{r}12,561 \\
1,826\end{array}$ & $\begin{array}{r}12,561 \\
1,826\end{array}$ & $\begin{array}{l}9,546 \\
1,483\end{array}$ & $\begin{array}{l}9,530 \\
1,482\end{array}$ & $\begin{array}{l}9,530 \\
1,482\end{array}$ \\
\hline$R^{2}$ & $13.37 \%$ & $14.00 \%$ & $46.14 \%$ & $46.58 \%$ & $53.87 \%$ & $68.90 \%$ \\
\hline
\end{tabular}

monthly stock returns. ${ }^{9}$ Firms with high return volatility are "riskier" than firms with low return volatility. We measure total return volatility because CEOs can influence both systematic and idiosyncratic volatility through corporate policy decisions. All models control for leverage and firm size.

Column 1 of Table 3 includes VEGA and DELTA to control for compensation wealth effects in the firm risk model. The impact of DELTA seems to dominate that of VEGA in the models, with DELTA positive and statistically significant

\footnotetext{
${ }^{9}$ Daily returns produce qualitatively similar results. Other possible measures of firm volatility include the variance of accounting performance measures (e.g., earnings, return on assets, return on equity). These measures require a long time series of annual data to estimate volatility, and so we favor the use of measures of return volatility over measures of accounting performance volatility.
} 
at the $1 \%$ level. In column 2, we add the PILOT variable and find that it is positive and significant, indicating that pilot CEOs are associated with a greater degree of stock return volatility within their firms beyond the amount explained by a wealth effect. This is one of the main contributions of our study.

The subsequent models include various control variables that could plausibly affect return volatility. We include year, industry, and firm fixed effects to control for legislation and other unobserved systematic differences along these dimensions. At the firm level, we include independent variables for R\&D expenses, sales growth, return on equity (ROE), the natural log of firm age, and market-to-book ratio (MB) to control for investment opportunities. At the CEO level, in addition to PILOT, our variable of interest, we include a series of age dummy variables and TENURE as independent control variables. ${ }^{10}$

The relation between PILOT and overall firm risk not only retains significance in all models, but also strengthens and increases in magnitude as controls are added. The results do not appear to be driven by certain time periods, differences across industries, or any variation in firm or CEO characteristics. Furthermore, when firm fixed effects are added to examine within-firm variation, the PILOT variable carries the largest coefficient of all specifications.

One way to place the magnitudes in context is to compare the pilot-CEO effect with that of other firm-specific determinants of firm risk. Leverage has a mechanical and (in theory) significant effect on firm risk and volatility. In column 5 of Table 3, which controls for both firm and industry effects, the coefficient on LEVERAGE is 0.077. Table 1 shows that LEVERAGE has a standard deviation of 0.186 . Thus, a 1-standard-deviation increase in LEVERAGE would increase return volatility by $0.077 \times 0.186=0.014$. In comparison, pilot CEOs in this column are associated with increases in return volatility of 0.032 , or more than double the effect of a 1-standard-deviation change in LEVERAGE. Thus, pilot CEOs appear to have a more significant impact on firm risk than do moderate changes in LEVERAGE. The economic magnitude of PILOT is even stronger in column 6 , but this could be due to the fact that firm fixed effects in this model control for the variation in characteristics across firms.

By similar calculations in column 5 of Table 3, a 1-standard-deviation change in $R \& D$ would increase volatility by $0.030(0.463 \times 0.065)$, sales growth by 0.012 $(0.043 \times 0.273)$, and ROE by $-0.053(-0.158 \times 0.333)$. The economic effect of having a pilot CEO thus falls within the same general range of effects from other firm-specific influences. The results are consistent with the interpretation that CEOs who bear elevated levels of health risk in their personal lives are willing to bear elevated levels of overall firm risk in their professional lives. Furthermore, because we control for wealth effects related to DELTA and VEGA, the tests in this section reveal that the elevated levels of corporate risk-taking associated with pilot CEOs are not driven exclusively by standard economic incentives contained within their compensation packages.

\footnotetext{
${ }^{10}$ In results reported in the Internet Appendix, we reestimate all models using the level of CEO age or log age and obtain qualitatively similar results.
} 


\section{B. Corporate Policies}

Leverage-increasing transactions mechanically increase firm risk. We test whether the group of risk-taking CEOs exhibits meaningful differences in capital structure, after controlling for differences in the operating environment.

Table 4 reports the results from these tests. We measure book leverage as total debt over total assets, winsorized at the $1 \%$ and $99 \%$ tails. ${ }^{11}$ We then regress our measure of leverage on our risk-taking proxy, controls for various other CEO characteristics, and firm-specific variables shown by prior literature to be significant determinants of leverage. ${ }^{12}$ Furthermore, to control for unobserved firm

\section{TABLE 4}

\section{Pilot CEOs and Firm Leverage}

\begin{tabular}{|c|c|c|c|c|}
\hline Independent Variables & 1 & 2 & 3 & 4 \\
\hline \multicolumn{5}{|c|}{ Panel A. CEO Characteristics } \\
\hline PILOT & $\begin{array}{c}0.019^{*} \\
(0.075)\end{array}$ & $\begin{array}{c}0.019^{*} \\
(0.068)\end{array}$ & $\begin{array}{c}0.025^{\star} \\
(0.053)\end{array}$ & $\begin{array}{l}0.025^{\star \star} \\
(0.044)\end{array}$ \\
\hline MILITARY & & & $\begin{array}{c}-0.021 \\
(0.234)\end{array}$ & $\begin{array}{c}-0.018 \\
(0.311)\end{array}$ \\
\hline AGE_40-49 & & & $\begin{array}{c}-0.031 \\
(0.267)\end{array}$ & $\begin{array}{c}-0.027 \\
(0.295)\end{array}$ \\
\hline AGE_50-59 & & & $\begin{array}{c}-0.029 \\
(0.307)\end{array}$ & $\begin{array}{c}-0.023 \\
(0.388)\end{array}$ \\
\hline$A G E \geq 60$ & & & $\begin{array}{c}-0.023 \\
(0.438)\end{array}$ & $\begin{array}{r}-0.016 \\
(0.554)\end{array}$ \\
\hline In(TENURE) & & & $\begin{array}{c}-0.002 \\
(0.512)\end{array}$ & $\begin{array}{c}-0.003 \\
(0.373)\end{array}$ \\
\hline VEGA & $\begin{array}{c}-0.014^{\star *} \\
(0.018)\end{array}$ & $\begin{array}{r}-0.011^{*} \\
(0.062)\end{array}$ & $\begin{array}{c}-0.013^{\star \star} \\
(0.034)\end{array}$ & $\begin{array}{r}-0.010 \\
(0.133)\end{array}$ \\
\hline DELTA & $\begin{array}{c}-0.011^{* \star *} \\
(0.003)\end{array}$ & $\begin{array}{c}-0.013^{\star \star \star *} \\
(0.000)\end{array}$ & $\begin{array}{c}-0.011^{* *} \\
(0.013)\end{array}$ & $\begin{array}{c}-0.013^{\star \star \star} \\
(0.002)\end{array}$ \\
\hline \multicolumn{5}{|c|}{ Panel B. Firm Characteristics } \\
\hline SALES_GROWTH & $\begin{array}{c}0.007 \\
(0.161)\end{array}$ & $\begin{array}{l}0.011^{\star *} \\
(0.050)\end{array}$ & $\begin{array}{c}0.003 \\
(0.658)\end{array}$ & $\begin{array}{c}0.007 \\
(0.276)\end{array}$ \\
\hline ROE & $\begin{array}{c}-0.033^{\text {*** }} \\
(0.000)\end{array}$ & $\begin{array}{c}-0.031^{\text {*** }} \\
(0.000)\end{array}$ & $\begin{array}{c}-0.030^{\star * *} \\
(0.000)\end{array}$ & $\begin{array}{c}-0.028^{* \star *} \\
(0.000)\end{array}$ \\
\hline MB & $\begin{array}{c}-0.015^{\star \star *} \\
(0.000)\end{array}$ & $\begin{array}{c}-0.016^{\star \star \star \star} \\
(0.000)\end{array}$ & $\begin{array}{c}-0.016^{\star \star *} \\
(0.000)\end{array}$ & 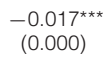 \\
\hline In(ASSETS) & $\begin{array}{l}0.019^{* * *} \\
(0.000)\end{array}$ & $\begin{array}{c}0.018^{\star \star} \\
(0.011)\end{array}$ & $\begin{array}{c}0.015^{\star *} \\
(0.032)\end{array}$ & $\begin{array}{c}0.012 \\
(0.185)\end{array}$ \\
\hline ASSET_TANGIBILITY & $\begin{array}{l}0.104^{* * *} \\
(0.009)\end{array}$ & $\begin{array}{c}0.094^{\star \star} \\
(0.024)\end{array}$ & $\begin{array}{r}0.084^{*} \\
(0.096)\end{array}$ & $\begin{array}{c}0.072 \\
(0.169)\end{array}$ \\
\hline Fixed effects & Firm & $\begin{array}{l}\text { Firm, } \\
\text { Year }\end{array}$ & Firm & $\begin{array}{l}\text { Firm, } \\
\text { Year }\end{array}$ \\
\hline $\begin{array}{l}\text { No. of obs. } \\
\text { No. of firms }\end{array}$ & $\begin{array}{r}12,734 \\
1,823\end{array}$ & $\begin{array}{r}12,734 \\
1,823\end{array}$ & $\begin{array}{l}9,551 \\
1,466\end{array}$ & $\begin{array}{l}9,551 \\
1,466\end{array}$ \\
\hline$R^{2}$ & $77.87 \%$ & $78.44 \%$ & $78.32 \%$ & $78.92 \%$ \\
\hline
\end{tabular}

\footnotetext{
${ }^{11}$ The results are qualitatively similar using market equity. We focus on book leverage because it is not subject to movements in market equity that may be unrelated to contemporaneous managerial choice regarding debt utilization.

${ }^{12}$ Malmendier, Tate, and Yan (2011) report that military experience and age are significant determinants of leverage. Firm-specific variables are based on Rajan and Zingales (1995).
} 
and/or time-specific factors that affect debt policy, we control for firm fixed effects in columns 1 and 3, and both firm and year fixed effects in columns 2 and 4. In both specifications, the PILOT dummy variable, our proxy for risk-taking behavior, is positively associated with leverage ratios, with statistical significance at the 5\% level in the presence of CEO-specific and year controls in column 4. The median sample firm has a LEVERAGE value of $22.0 \%$, implying that pilot CEOs are associated with $11.4 \%(0.025 / 22 \%)$ higher firm leverage, at the median. However, because we control for leverage in our tests of the relation between personal risk-taking and firm risk in Table 3, it follows that additional channels exist through which pilot CEOs increase firm risk.

Graham et al. (2015) document that CEOs are more likely to retain the decision-making authority for mergers and acquisitions relative to other corporate policies. Furthermore, Graham, Harvey, and Puri's (2012) evidence from survey data suggests that CEO characteristics, particularly as they pertain to risk preferences, matter in acquisition activity. We hypothesize that if risk-taking tendencies are present in CEOs, a corporate corollary to the increased trading frequency observed in sensation-seeking retail investors will manifest in higher acquisition frequency. ${ }^{13}$ Higher acquisition activity would also be consistent with more risktolerant CEOs bypassing risky investment opportunities with lower frequency.

Table 5 reports estimates from logit models in which the dependent variable equals 1 if a firm announces a successful bid in a given year, and 0 otherwise. ${ }^{14}$ M\&A transaction data come from the Thomson Reuters SDC Platinum database. We include a number of control variables that have been shown to impact the likelihood of engagement in M\&A activity: leverage, dividend yield, an indicator for net loss firm-years (LOSS_DUMMY), the natural log of total assets, free cash flow, Tobin's $Q$, and capital expenditures (Bauguess and Stegemoller (2008), Harford, Humphery-Jenner, and Powell (2012), and Malmendier and Tate (2008)). The construction of these variables is explained in the Appendix. Coefficients are reported as odds ratios; thus, a coefficient greater than 1 is positive, and less than 1 is negative.

In column 1 of Table 5, the coefficient on the PILOT variable is greater than 1 and statistically significant at the $10 \%$ level, indicating that pilot CEOs are more likely to complete acquisitions. In columns 2 and 3, we control for industry fixed effects and year fixed effects, with column 3 reporting results from a model that includes both controls. The coefficient on the PILOT variable remains positive and strengthens to significance at the 5\% level. CEOs are more likely to make acquisitions later during their tenure with the firm, with the coefficient on TENURE being greater than 1 and significant at the $1 \%$ level. ${ }^{15}$ One concern with the results thus far is that pilot CEOs may simply be drawn to firms that are already more acquisition-driven. One way to evaluate this concern would be to include firm

\footnotetext{
${ }^{13}$ In addition to risk preferences, CEOs may also have separate financial incentives to engage in M\&A activity (see, e.g., Harford and Li (2007)).

${ }^{14}$ We follow Malmendier and Tate (2008) in counting only bids that are eventually successful. Our results are qualitatively similar if we include both successful and unsuccessful bids.

${ }^{15}$ Identification for both the AGE and TENURE variables requires that some CEOs switch firms during the sample period, which resets TENURE but not AGE.
} 


\section{TABLE 5}

Acquisitiveness of Pilot CEOs

\begin{tabular}{|c|c|c|c|c|}
\hline Independent Variables & 1 & 2 & 3 & 4 \\
\hline \multicolumn{5}{|c|}{ Panel A. CEO Characteristics } \\
\hline PILOT & $\begin{array}{c}1.267^{\star} \\
(0.071)\end{array}$ & $\begin{array}{l}1.389^{\star \star} \\
(0.026)\end{array}$ & $\begin{array}{l}1.332^{\star *} \\
(0.038)\end{array}$ & $\begin{array}{l}1.593^{\star \star} \\
(0.047)\end{array}$ \\
\hline MILITARY & & $\begin{array}{c}0.842 \\
(0.233)\end{array}$ & $\begin{array}{c}0.932 \\
(0.608)\end{array}$ & $\begin{array}{c}0.842 \\
(0.398)\end{array}$ \\
\hline AGE_40-49 & & $\begin{array}{c}1.385 \\
(0.309)\end{array}$ & $\begin{array}{c}1.494 \\
(0.198)\end{array}$ & $\begin{array}{c}1.775 \\
(0.133)\end{array}$ \\
\hline AGE_50-59 & & $\begin{array}{c}1.265 \\
(0.468)\end{array}$ & $\begin{array}{c}1.454 \\
(0.233)\end{array}$ & $\begin{array}{c}1.604 \\
(0.238)\end{array}$ \\
\hline$A G E \geq 60$ & & $\begin{array}{c}1.023 \\
(0.945)\end{array}$ & $\begin{array}{c}1.203 \\
(0.564)\end{array}$ & $\begin{array}{c}1.364 \\
(0.453)\end{array}$ \\
\hline In(TENURE) & & $\begin{array}{l}1.181^{\star \star \star} \\
(0.000)\end{array}$ & $\begin{array}{l}1.166^{\star \star \star} \\
(0.001)\end{array}$ & $\begin{array}{l}1.163^{\star \star \star \star} \\
(0.009)\end{array}$ \\
\hline VEGA & $\begin{array}{c}1.222^{*} \\
(0.083)\end{array}$ & $\begin{array}{c}1.117 \\
(0.389)\end{array}$ & $\begin{array}{c}0.931 \\
(0.562)\end{array}$ & $\begin{array}{c}0.993 \\
(0.966)\end{array}$ \\
\hline DELTA & $\begin{array}{c}1.103^{*} \\
(0.061)\end{array}$ & $\begin{array}{l}1.180^{\star \star \star} \\
(0.009)\end{array}$ & $\begin{array}{l}1.152^{\star *} \\
(0.018)\end{array}$ & $\begin{array}{c}1.163^{\star} \\
(0.061)\end{array}$ \\
\hline \multicolumn{5}{|c|}{ Panel B. Firm Characteristics } \\
\hline LEVERAGE & $\begin{array}{c}0.764 \\
(0.136)\end{array}$ & $\begin{array}{c}0.650^{\star \star} \\
(0.040)\end{array}$ & $\begin{array}{c}1.129 \\
(0.569)\end{array}$ & $\begin{array}{c}1.041 \\
(0.900)\end{array}$ \\
\hline DIVIDEND_YIELD & $\begin{array}{l}0.000^{* \star *} \\
(0.000)\end{array}$ & $\begin{array}{l}0.000^{\star \star \star} \\
(0.000)\end{array}$ & $\begin{array}{l}0.013^{* *} \\
(0.047)\end{array}$ & $\begin{array}{c}0.155 \\
(0.442)\end{array}$ \\
\hline LOSS_DUMMY & $\begin{array}{r}0.864^{*} \\
(0.073)\end{array}$ & $\begin{array}{c}0.875 \\
(0.151)\end{array}$ & $\begin{array}{l}0.774^{\text {*** }} \\
(0.006)\end{array}$ & $\begin{array}{c}0.833^{\star} \\
(0.083)\end{array}$ \\
\hline In(ASSETS) & $\begin{array}{l}1.247^{\star \star *} \\
(0.000)\end{array}$ & $\begin{array}{l}1.234^{\star \star \star} \\
(0.000)\end{array}$ & $\begin{array}{l}1.359^{* * *} \\
(0.000)\end{array}$ & 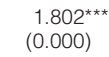 \\
\hline FREE_CASH_FLOW & $\begin{array}{l}3.743^{* * *} \\
(0.000)\end{array}$ & $\begin{array}{l}6.537^{\star \star \star} \\
(0.000)\end{array}$ & $\begin{array}{l}6.562^{* * *} \\
(0.000)\end{array}$ & $\begin{array}{l}6.789^{* \star \star} \\
(0.001)\end{array}$ \\
\hline Q & 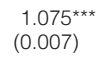 & $\begin{array}{c}1.051 \\
(0.120)\end{array}$ & $\begin{array}{c}0.972 \\
(0.375)\end{array}$ & $\begin{array}{c}1.039 \\
(0.393)\end{array}$ \\
\hline CAPEX & $\begin{array}{l}14.008^{\star * *} \\
(0.000)\end{array}$ & $\begin{array}{l}13.234^{\star \star \star} \\
(0.000)\end{array}$ & $\begin{array}{l}62.837^{* * *} \\
(0.000)\end{array}$ & $\begin{array}{c}415.064^{\text {*** }} \\
(0.000)\end{array}$ \\
\hline Fixed effects & None & Year & $\begin{array}{l}\text { Industry, } \\
\text { Year }\end{array}$ & $\begin{array}{l}\text { Firm, } \\
\text { Year }\end{array}$ \\
\hline $\begin{array}{l}\text { No. of obs. } \\
\text { No. of firms }\end{array}$ & $\begin{array}{r}11,578 \\
1,693\end{array}$ & $\begin{array}{l}8,649 \\
1,367\end{array}$ & $\begin{array}{l}8,649 \\
1,367\end{array}$ & $\begin{array}{r}6,072 \\
784\end{array}$ \\
\hline Pseudo- $R^{2}$ & $36.42 \%$ & $50.36 \%$ & $53.42 \%$ & $73.37 \%$ \\
\hline
\end{tabular}

fixed effects in the models. However, our pilot-status CEO turnover sample is limited, and many firms engage in M\&A only infrequently. Inclusion of firm fixed effects could thus bias the coefficients. Despite this concern, in column 4 we include firm fixed effects. We note that the coefficient on PILOT remains positive and significant; however, the magnitude increases substantially from that in column 3. This could reflect a bias concern. As a result, it is likely that the magnitude of the coefficient in column 3 represents a reasonable interpretation of the results; that is, pilot CEOs are about 1.33 times more likely to complete an acquisition in any given year than are nonpilot CEOs.

M\&A activity is only one of the avenues through which executives pursue corporate growth; internal investment is an alternative path. It is possible that 
sensation seekers substitute external for internal growth prospects; alternatively, it is possible that capital expenditures and acquisitions are complements for one another as sensation seekers pursue overall corporate growth. In the Internet Appendix, we evaluate the ratios of capital expenditures to assets and find that capital expenditures are positively associated with pilot CEOs. ${ }^{16}$ These results indicate that capital expenditures and M\&A activity are complements of one another, as risk-tolerant CEOs accept projects of both types at an increased rate relative to their peers.

In the Internet Appendix, we examine whether characteristics of the acquirers or targets differ systematically between firms led by pilot CEOs and those led by nonpilot CEOs. We do not find any significant differences in the rates of the targets' public status, method of payment (cash/stock), cross-industry diversity, international status of targets, offer premium amounts, or target industry Tobin's $Q$ ratios. However, pilot CEOs tend to complete acquisitions of targets that are smaller in size relative to the bidder as compared with nonpilot CEO acquisitions. This difference is significant at the 5\% level. Because the most value-destroying acquisitions are those that are largest in absolute and relative size (Moeller, Schlingemann, and Stulz (2004)), this result is consistent with our finding that pilot CEOs execute mergers that are at least as beneficial as those completed by nonpilot CEOs, on average.

\section{M\&A Activity and Firm Risk}

Our prior tests indicate that risk-taking CEOs are associated with significantly higher leverage and acquisition activity. The effect of M\&A transactions on firm risk, however, is ambiguous. If acquisitions are diversifying, firm risk could decrease (Amihud and Lev (1981)). Alternatively, a low-beta firm acquiring a high-beta firm could increase the volatility of returns to equity. In Table 6, we explore the extent to which M\&A activity drives the elevated corporate risk documented in Table 3. To do so, we now include a binary variable, M\&A_ACTIVITY, which equals 1 if the firm completes an acquisition in the given year, and 0 otherwise. We also interact this indicator variable with the PILOT variable. We include controls for industry fixed effects instead of firm fixed effects due to the small amount of within-firm variation in M\&A activity levels.

Columns 1-4 of Table 6 report results from these models. The coefficient on PILOT is lower in both magnitude and statistical significance in these columns when compared with Table 3, whereas the coefficient on M\&A_ACTIVITY is negative in all models, significantly so in the presence of fixed effects for industry and year. The coefficient on the interaction of PILOT and M\&A_ ACTIVITY is positive and significant in all columns. Thus, it appears that although M\&A_ACTIVITY on average does not increase firm risk, the types of transactions executed by risk-seeking CEOs do tend to increase the riskiness of

\footnotetext{
${ }^{16}$ These models are ordinary least squares (OLS) regressions with independent variables including CEO characteristics, beginning-of-year leverage, dividend yield, loss dummy, natural log of total assets, free cash flow, Tobin's $Q$, and year/industry fixed effects. The dependent variable is the firm's capital expenditures scaled by beginning-of-year total assets.
} 


\section{TABLE 6}

The Influence of M\&A Activity on Firm Risk

\begin{tabular}{|c|c|c|c|c|}
\hline Independent Variables & 1 & 2 & 3 & 4 \\
\hline PILOT & $\begin{array}{c}0.010 \\
(0.247)\end{array}$ & $\begin{array}{c}0.013 \\
(0.220)\end{array}$ & $\begin{array}{l}0.017 \\
(0.152)\end{array}$ & $\begin{array}{l}0.024^{* *} \\
(0.026)\end{array}$ \\
\hline M\&A_ACTIVITY & $\begin{array}{c}-0.003 \\
(0.468)\end{array}$ & $\begin{array}{l}-0.022^{\star \star *} \\
(0.000)\end{array}$ & $\begin{array}{l}-0.026^{\star \star \star} \\
(0.000)\end{array}$ & $\begin{array}{l}-0.023^{\star \star \star} \\
(0.000)\end{array}$ \\
\hline PILOT $\times$ M\&A_ACTIVITY & $\begin{array}{l}0.044^{\star \star} \\
(0.023)\end{array}$ & $\begin{array}{r}0.033^{*} \\
(0.072)\end{array}$ & $\begin{array}{l}0.042^{\star \star} \\
(0.034)\end{array}$ & $\begin{array}{l}0.032^{*} \\
(0.069)\end{array}$ \\
\hline VEGA & $\begin{array}{c}-0.011 \\
(0.224)\end{array}$ & $\begin{array}{l}-0.035^{\star * *} \\
(0.000)\end{array}$ & $\begin{array}{l}-0.039^{\star \star \star} \\
(0.001)\end{array}$ & $\begin{array}{l}-0.038^{* \star \star} \\
(0.000)\end{array}$ \\
\hline DELTA & $\begin{array}{l}0.037^{\star \star \star} \\
(0.000)\end{array}$ & $\begin{array}{l}0.017^{\star * *} \\
(0.000)\end{array}$ & $\begin{array}{l}0.026^{\star \star \star} \\
(0.000)\end{array}$ & $\begin{array}{l}0.020^{\star \star \star} \\
(0.000)\end{array}$ \\
\hline MILITARY & & & $\begin{array}{r}-0.014 \\
(0.155)\end{array}$ & $\begin{array}{r}-0.015^{*} \\
(0.087)\end{array}$ \\
\hline AGE_40-49 & & & $\begin{array}{l}-0.063^{\star \star \star} \\
(0.004)\end{array}$ & $\begin{array}{l}-0.060^{* \star \star} \\
(0.004)\end{array}$ \\
\hline AGE_50-59 & & & $\begin{array}{l}-0.082^{\star \star \star} \\
(0.000)\end{array}$ & $\begin{array}{l}-0.072^{\text {** }} \\
(0.001)\end{array}$ \\
\hline $\mathrm{AGE} \geq 60$ & & & $\begin{array}{l}-0.079^{\star \star \star} \\
(0.000)\end{array}$ & $\begin{array}{l}-0.069^{* \star *} \\
(0.001)\end{array}$ \\
\hline In(TENURE) & & & $\begin{array}{l}-0.011^{\star * *} \\
(0.001)\end{array}$ & $\begin{array}{l}-0.009^{* * *} \\
(0.006)\end{array}$ \\
\hline In(ASSETS) & $\begin{array}{l}-0.054^{\star \star \star *} \\
(0.000)\end{array}$ & $\begin{array}{l}-0.043^{* * *} \\
(0.000)\end{array}$ & $\begin{array}{l}-0.041^{\star * *} \\
(0.000)\end{array}$ & $\begin{array}{l}-0.027^{\text {** }} \\
(0.000)\end{array}$ \\
\hline LEVERAGE & $\begin{array}{l}0.073^{\star \star \star} \\
(0.000)\end{array}$ & $\begin{array}{l}0.128^{* * *} \\
(0.000)\end{array}$ & $\begin{array}{l}0.135^{\star \star \star} \\
(0.000)\end{array}$ & $\begin{array}{l}0.077^{* * *} \\
(0.000)\end{array}$ \\
\hline R\&D & & & & $\begin{array}{l}0.461^{* * *} \\
(0.000)\end{array}$ \\
\hline SALES_GROWTH & & & & 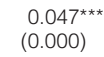 \\
\hline ROE & & & & $\begin{array}{l}-0.156^{* * *} \\
(0.000)\end{array}$ \\
\hline MB & & & & $\begin{array}{c}-0.002 \\
(0.460)\end{array}$ \\
\hline In(FIRM_AGE) & & & & $\begin{array}{l}-0.032^{\star \star \star} \\
(0.000)\end{array}$ \\
\hline Fixed effects & None & $\begin{array}{l}\text { Industry, } \\
\text { Year }\end{array}$ & $\begin{array}{l}\text { Industry, } \\
\text { Year }\end{array}$ & $\begin{array}{l}\text { Industry, } \\
\text { Year }\end{array}$ \\
\hline $\begin{array}{l}\text { No. of obs. } \\
\text { No. of firms }\end{array}$ & $\begin{array}{r}12,561 \\
1,826\end{array}$ & $\begin{array}{r}12,561 \\
1,826\end{array}$ & $\begin{array}{l}9,546 \\
1,483\end{array}$ & $\begin{array}{l}9,530 \\
1,482\end{array}$ \\
\hline$R^{2}$ & $14.04 \%$ & $46.28 \%$ & $46.79 \%$ & $54.03 \%$ \\
\hline
\end{tabular}

their firms. To summarize the findings, a substantial amount of the increase in firm risk associated with pilot CEOs arises from the CEOs' increased propensity for making acquisitions that increase risk for the acquiring firm. Nonetheless, the PILOT variable remains statistically significant in column 4, indicating that these CEOs pursue additional corporate policies that positively impact their firms' return volatility.

\section{Personal Risk-Taking and Shareholder Value}

Next, we turn to the question of whether CEOs with elevated risk tolerance are beneficial or detrimental to shareholder value. Again, the theoretical 
prediction is ambiguous. As stated previously, risk-averse managers can impose agency costs on shareholders by passing up projects that are risky but also have positive net present value (NPV). To the extent that our proxy for personal risktaking indicates a characteristic that reduces risk aversion in project selection, then shareholder value should be enhanced. However, if the characteristic we identify indicates that the CEOs' preferences have crossed the threshold for risk neutrality into the risk-seeking domain, then shareholder value is likely to be destroyed. Acquisition announcements are a moment in time in which project selection is revealed to the market. Therefore, we examine announcement returns split along a variety of dimensions, such as governance and organic investment opportunities, to discern whether shareholder value is significantly impacted in either direction by the project selection of pilot CEOs.

Rau and Vermaelen (1998) show that managerial hubris may be amplified among "glamour firms" (i.e., firms with market values that have risen sharply in recent months). CEOs in these firms may incorrectly attribute the high market values to their own capabilities and subsequently overbid on acquisition opportunities. The authors dub this "performance extrapolation" and document that low-book-to-market glamour firms experience negative abnormal performance following acquisitions. If pilot CEOs pursue similarly value-reducing acquisition targets, we would expect these to produce returns lower than deals closed by nonpilot CEOs. This effect could be more pronounced among glamour firms.

On the other hand, to the extent that pilot CEOs are more willing to take on risky but value-enhancing projects, then acquisition returns among high-bookto-market "value firms" may be greater (Rau and Vermaelen (1998)). In firms with fewer recognizable investment opportunities (i.e., value firms), acquisitions are likely to be a more important channel for project selection, and risk-tolerant CEOs may be more beneficial among these high-book-to-market firms.

To test the value creation of pilot CEOs' investment activities, we evaluate the announcement-period returns of sample bidders relative to CEO characteristics and other controls. Table 7 reports OLS regressions using bidder announcement returns as the dependent variable. Following Malmendier and Tate (2008), we measure cumulative abnormal returns over the $(-1,+1)$ window around merger announcements, using the S\&P 500 Index as the benchmark expected return. We include the following transaction characteristics as control variables: an indicator for cash payment, the natural log of transaction value, an indicator for private targets, and an indicator for transactions with different bidder and target 3-digit SIC codes (DIVERSIFYING). We also include bidder characteristics from prior tables, but lagged by 1 year because announcement returns occur prior to yearend. All independent variables are defined in greater detail in the Appendix. Due to the smaller sample of M\&A announcements, we do not include firm fixed effects in these models.

In column 1 of Table 7, bidder returns are unrelated to PILOT and AGE. Thus, on average, the personal risk-taking proxy does not appear to be significantly related to the quality of acquisitions in our sample. Column 2 includes both year and industry fixed effects, and the results are similar.

We next turn to evaluating whether returns differ between glamour and value acquirers. We measure the ratio of book equity to market value of equity (BM) in 


\section{TABLE 7}

\section{Pilot CEOs and M\&A Announcement Returns}

Table 7 reports the results of OLS regressions with bidder announcement returns as the dependent variable. Abnormal returns are calculated over the window from 1 day prior to 1 day following merger announcements $(-1,+1)$, using the S\&P 500 Index as the expected return. A constant is included in all models. Independent variables are defined in the Appendix; all bidder characteristics are lagged by 1 year. Standard errors are clustered by firm and year, and $p$-values are in parentheses. ${ }^{* \star},{ }^{* \star}$, and ${ }^{*}$ indicate significance at the $1 \%, 5 \%$, and $10 \%$ levels, respectively.

\begin{tabular}{|c|c|c|c|c|c|c|}
\hline \multirow[b]{2}{*}{ Independent Variables } & \multicolumn{2}{|c|}{ Full Sample } & \multicolumn{2}{|c|}{ Low-BM Bidders } & \multicolumn{2}{|c|}{ High-BM Bidders } \\
\hline & 1 & 2 & 3 & 4 & 5 & 6 \\
\hline \multicolumn{7}{|c|}{ Panel A. CEO Characteristics } \\
\hline PILOT & $\begin{array}{c}0.444 \\
(0.330)\end{array}$ & $\begin{array}{c}0.342 \\
(0.484)\end{array}$ & $\begin{array}{c}0.299 \\
(0.699)\end{array}$ & $\begin{array}{c}0.206 \\
(0.783)\end{array}$ & $\begin{array}{c}0.825^{\star} \\
(0.079)\end{array}$ & $\begin{array}{c}0.851^{*} \\
(0.094)\end{array}$ \\
\hline MILITARY & $\begin{array}{r}-0.112 \\
(0.821)\end{array}$ & $\begin{array}{r}-0.169 \\
(0.739)\end{array}$ & $\begin{array}{r}-0.208 \\
(0.788)\end{array}$ & $\begin{array}{r}-0.201 \\
(0.808)\end{array}$ & $\begin{array}{c}0.020 \\
(0.972)\end{array}$ & $\begin{array}{r}-0.319 \\
(0.598)\end{array}$ \\
\hline VEGA & $\begin{array}{c}0.073 \\
(0.596)\end{array}$ & $\begin{array}{c}0.039 \\
(0.783)\end{array}$ & $\begin{array}{c}0.061 \\
(0.694)\end{array}$ & $\begin{array}{r}-0.005 \\
(0.976)\end{array}$ & $\begin{array}{c}0.328 \\
(0.674)\end{array}$ & $\begin{array}{r}-0.074 \\
(0.910)\end{array}$ \\
\hline DELTA & $\begin{array}{l}0.660^{* * *} \\
(0.002)\end{array}$ & $\begin{array}{l}0.630^{\star \star \star} \\
(0.003)\end{array}$ & $\begin{array}{l}0.854^{\star *} \\
(0.030)\end{array}$ & $\begin{array}{r}0.788^{*} \\
(0.054)\end{array}$ & $\begin{array}{c}0.277 \\
(0.146)\end{array}$ & $\begin{array}{l}0.366^{\star \star} \\
(0.018)\end{array}$ \\
\hline AGE_40-49 & $\begin{array}{r}-1.497 \\
(0.494)\end{array}$ & $\begin{array}{r}-1.522 \\
(0.515)\end{array}$ & $\begin{array}{r}-2.093 \\
(0.521)\end{array}$ & $\begin{array}{r}-1.965 \\
(0.564)\end{array}$ & $\begin{array}{r}-0.911 \\
(0.528)\end{array}$ & $\begin{array}{r}-0.823 \\
(0.596)\end{array}$ \\
\hline AGE_50-59 & $\begin{array}{r}-1.276 \\
(0.581)\end{array}$ & $\begin{array}{r}-1.311 \\
(0.592)\end{array}$ & $\begin{array}{r}-1.512 \\
(0.656)\end{array}$ & $\begin{array}{r}-1.417 \\
(0.690)\end{array}$ & $\begin{array}{r}-1.158 \\
(0.384)\end{array}$ & $\begin{array}{r}-1.129 \\
(0.447)\end{array}$ \\
\hline$A G E \geq 60$ & $\begin{array}{r}-1.574 \\
(0.485)\end{array}$ & $\begin{array}{r}-1.624 \\
(0.501)\end{array}$ & $\begin{array}{r}-1.864 \\
(0.573)\end{array}$ & $\begin{array}{r}-1.674 \\
(0.629)\end{array}$ & $\begin{array}{r}-1.204 \\
(0.492)\end{array}$ & $\begin{array}{r}-1.234 \\
(0.514)\end{array}$ \\
\hline In(TENURE) & $\begin{array}{c}-0.447^{\star \star *} \\
(0.006)\end{array}$ & $\begin{array}{c}-0.344^{\star \star} \\
(0.037)\end{array}$ & $\begin{array}{c}-0.659^{\star \star \star} \\
(0.010)\end{array}$ & $\begin{array}{r}-0.467^{\star} \\
(0.075)\end{array}$ & $\begin{array}{r}-0.234 \\
(0.279)\end{array}$ & $\begin{array}{r}-0.115 \\
(0.625)\end{array}$ \\
\hline \multicolumn{7}{|c|}{ Panel B. Bidder Characteristics } \\
\hline In(FIRM_AGE) & $\begin{array}{c}0.209 \\
(0.302)\end{array}$ & $\begin{array}{c}0.275 \\
(0.196)\end{array}$ & $\begin{array}{r}-0.151 \\
(0.602)\end{array}$ & $\begin{array}{c}-0.044 \\
(0.877)\end{array}$ & $\begin{array}{c}0.603^{\star} \\
(0.072)\end{array}$ & $\begin{array}{l}0.630^{* *} \\
(0.049)\end{array}$ \\
\hline FREE_CASH_FLOW & $\begin{array}{r}-0.524 \\
(0.379)\end{array}$ & $\begin{array}{r}-0.550 \\
(0.378)\end{array}$ & $\begin{array}{r}-0.397 \\
(0.449)\end{array}$ & $\begin{array}{r}-0.411 \\
(0.466)\end{array}$ & $\begin{array}{r}-1.700 \\
(0.561)\end{array}$ & $\begin{array}{r}-1.517 \\
(0.601)\end{array}$ \\
\hline CAPEX & $\begin{array}{l}2.166^{* *} \\
(0.035)\end{array}$ & $\begin{array}{c}1.781^{\star} \\
(0.084)\end{array}$ & $\begin{array}{c}2.884 \\
(0.134)\end{array}$ & $\begin{array}{c}2.051 \\
(0.288)\end{array}$ & $\begin{array}{c}0.697 \\
(0.720)\end{array}$ & $\begin{array}{c}0.590 \\
(0.776)\end{array}$ \\
\hline $\ln ($ ASSETS) & $\begin{array}{c}-0.534^{\star * *} \\
(0.000)\end{array}$ & $\begin{array}{c}-0.513^{\star \star \star} \\
(0.000)\end{array}$ & $\begin{array}{c}-0.614^{\star \star} \\
(0.017)\end{array}$ & $\begin{array}{c}-0.581^{* *} \\
(0.032)\end{array}$ & $\begin{array}{c}-0.401^{\star \star} \\
(0.014)\end{array}$ & $\begin{array}{c}-0.354^{\star \star} \\
(0.016)\end{array}$ \\
\hline LOSS_DUMMY & $\begin{array}{c}0.637 \\
(0.441)\end{array}$ & $\begin{array}{c}0.712 \\
(0.390)\end{array}$ & $\begin{array}{c}0.936 \\
(0.663)\end{array}$ & $\begin{array}{c}1.368 \\
(0.539)\end{array}$ & $\begin{array}{c}0.328 \\
(0.376)\end{array}$ & $\begin{array}{c}0.320 \\
(0.412)\end{array}$ \\
\hline LEVERAGE & $\begin{array}{c}1.721^{*} \\
(0.071)\end{array}$ & $\begin{array}{c}1.642^{\star} \\
(0.096)\end{array}$ & $\begin{array}{c}2.063 \\
(0.179)\end{array}$ & $\begin{array}{c}1.979 \\
(0.207)\end{array}$ & $\begin{array}{c}0.757 \\
(0.572)\end{array}$ & $\begin{array}{c}0.512 \\
(0.678)\end{array}$ \\
\hline DIVIDEND_YIELD & $\begin{array}{c}8.001 \\
(0.547)\end{array}$ & $\begin{array}{c}3.880 \\
(0.781)\end{array}$ & $\begin{array}{c}31.248 \\
(0.164)\end{array}$ & $\begin{array}{c}25.281 \\
(0.288)\end{array}$ & $\begin{array}{r}-6.403 \\
(0.741)\end{array}$ & $\begin{array}{r}-8.521 \\
(0.675)\end{array}$ \\
\hline \multicolumn{7}{|c|}{ Panel C. Transaction Characteristics } \\
\hline CASH_PAYMENT & $\begin{array}{c}0.436 \\
(0.134)\end{array}$ & $\begin{array}{l}0.594^{\star \star} \\
(0.047)\end{array}$ & $\begin{array}{l}1.086^{\star \star \star} \\
(0.007)\end{array}$ & $\begin{array}{l}1.415^{\star \star *} \\
(0.001)\end{array}$ & $\begin{array}{r}-0.203 \\
(0.631)\end{array}$ & $\begin{array}{r}-0.149 \\
(0.715)\end{array}$ \\
\hline In(TRANS_VALUE) & $\begin{array}{r}-0.018 \\
(0.861)\end{array}$ & $\begin{array}{r}-0.014 \\
(0.899)\end{array}$ & $\begin{array}{c}0.110 \\
(0.549)\end{array}$ & $\begin{array}{c}0.089 \\
(0.642)\end{array}$ & $\begin{array}{r}-0.143 \\
(0.141)\end{array}$ & $\begin{array}{r}-0.139 \\
(0.134)\end{array}$ \\
\hline PRIVATE_TARGET & $\begin{array}{l}1.991^{* * *} \\
(0.000)\end{array}$ & $\begin{array}{l}2.082^{\star \star \star} \\
(0.000)\end{array}$ & $\begin{array}{l}2.128^{\star \star *} \\
(0.000)\end{array}$ & $\begin{array}{l}2.255^{\star * *} \\
(0.000)\end{array}$ & $\begin{array}{l}1.925^{\star \star \star} \\
(0.000)\end{array}$ & $\begin{array}{l}1.866 \text { *** } \\
(0.000)\end{array}$ \\
\hline DIVERSIFYING & $\begin{array}{r}-0.080 \\
(0.775)\end{array}$ & $\begin{array}{r}-0.125 \\
(0.660)\end{array}$ & $\begin{array}{r}-0.116 \\
(0.763)\end{array}$ & $\begin{array}{r}-0.186 \\
(0.606)\end{array}$ & $\begin{array}{r}-0.013 \\
(0.973)\end{array}$ & $\begin{array}{c}0.025 \\
(0.952)\end{array}$ \\
\hline Fixed effects & Industry & $\begin{array}{l}\text { Industry, } \\
\text { Year }\end{array}$ & Industry & $\begin{array}{l}\text { Industry, } \\
\text { Year }\end{array}$ & Industry & $\begin{array}{l}\text { Industry, } \\
\text { Year }\end{array}$ \\
\hline No. of obs. & 2,467 & 2,467 & 1,303 & 1,303 & 1,164 & 1,164 \\
\hline $\begin{array}{l}\text { No. of firms } \\
R^{2}\end{array}$ & $\begin{array}{r}742 \\
5.76 \%\end{array}$ & $\begin{array}{r}742 \\
6.18 \%\end{array}$ & $\begin{array}{r}399 \\
7.12 \%\end{array}$ & $\begin{array}{r}399 \\
7.91 \%\end{array}$ & $\begin{array}{r}489 \\
7.77 \%\end{array}$ & $\begin{array}{r}489 \\
9.34 \%\end{array}$ \\
\hline
\end{tabular}

the year prior to acquisition announcement, with high-BM firms being value firms and low-BM firms being glamour firms. We assign firms to either low-BM or high-BM bins based on the New York Stock Exchange (NYSE) breakpoints listed 
on Kenneth French's Web site (http://mba.tuck.dartmouth.edu/pages/faculty/ ken.french/data_library.html). ${ }^{17}$ Columns 3 and 4 of Table 7 report results from the bidder return regression in the low-BM subsample, and show no significant effect of PILOT. In column 5, we compute a similar model of bidder returns in the high-BM value-firm subsample of bidders. The coefficient on PILOT is positive and significant at the $10 \%$ level. Results are similar in column 6, which includes both year and industry fixed effects. The results are consistent with the hypothesis that risk-tolerant CEOs pursue value-increasing acquisitions at bidders with few recognizable organic growth prospects. We conclude that in at least certain firm types, pilot CEOs can create value by pursuing a policy of heightened M\&A activity.

In the Internet Appendix, we evaluate announcement returns for the interaction of pilot CEOs and the quality of their firms' corporate governance. We evaluate numerous proxies for corporate governance quality: the G-Index, the E-Index, staggered boards, board size, the percentage of independent board members, board ownership, and CEO-chairman dual roles. Overall, we fail to find a significant interaction between pilot CEOs and corporate governance as it relates to the quality of merger target selection. In summary, we document no significant evidence that the type of risk tolerance we identify is detrimental to shareholders, and in some cases (e.g., among value firms) it may be beneficial.

\section{E. Compensation Structure}

We conclude our analysis by examining the relation between personal risktaking and compensation structure for two reasons. First, prior studies have linked compensation convexity to corporate risk-taking; therefore it is important to understand how our proxy relates to compensation structure. ${ }^{18}$ Second, if our proxy is associated with riskier compensation, it would provide a degree of internal consistency in that the proxy is associated with risk preferences. In this regard, the theoretical prediction is clear cut: if pilot CEOs are less risk averse, they should be more willing to bear firm-specific risk, which means performance-based incentives are less costly for the firm to provide. The complicating factor is that if pilot CEOs are less risk averse, they need fewer incentives to mitigate the misalignment with risk-neutral shareholders. This effect would attenuate the expected positive relation between risk tolerance and equity compensation, thereby creating ambiguity in the expected sign.

Table 8 reports results from OLS regressions of compensation measures on our risk-taking proxy, controls for other CEO characteristics, and controls for firm-specific attributes that determine compensation structure. In columns 1-3, the dependent variable is the sensitivity of the CEO's option portfolio to stock return volatility (VEGA), following Guay (1999). In column 1, the PILOT variable is significantly positively related to VEGA, controlling for other facets of the com-

\footnotetext{
${ }^{17}$ We assign firms to the bins using the 25th-percentile breakpoint each year, as this produces a balanced sample of approximately $50 \%$ of firm-year announcements in each bin. Thus, our sample of acquirers is not representative of the overall sample of NYSE firms based on BM rankings.

${ }^{18}$ See, for example, Guay (1999), Coles et al. (2006), Low (2009), and Chava and Purnanandam (2010).
} 
TABLE 8

Compensation Structure

\begin{tabular}{|c|c|c|c|c|c|c|}
\hline \multirow[b]{2}{*}{ Independent Variables } & \multicolumn{3}{|c|}{ VEGA } & \multicolumn{2}{|c|}{$\begin{array}{c}\text { HIGH_- } \\
\text { PERFORMANCE_PAY }\end{array}$} & \multirow{2}{*}{$\begin{array}{c}\text { TOTAL_ } \\
\text { COMPENSATION } \\
6 \\
\end{array}$} \\
\hline & 1 & 2 & 3 & 4 & 5 & \\
\hline PILOT & $\begin{array}{c}0.024^{* *} \\
(0.019)\end{array}$ & $\begin{array}{c}0.023^{\star \star} \\
(0.016)\end{array}$ & $\begin{array}{c}0.011 \\
(0.195)\end{array}$ & $\begin{array}{c}0.180^{* *} \\
(0.019)\end{array}$ & $\begin{array}{l}0.200^{\star *} \\
(0.013)\end{array}$ & $\begin{array}{c}0.020 \\
(0.554)\end{array}$ \\
\hline $\ln (\mathrm{DELTA})$ & $\begin{array}{l}0.059^{* * *} \\
(0.000)\end{array}$ & $\begin{array}{l}0.061^{\star \star \star} \\
(0.000)\end{array}$ & $\begin{array}{l}0.046^{* * *} \\
(0.000)\end{array}$ & $\begin{array}{l}0.400^{\star \star \star} \\
(0.000)\end{array}$ & $\begin{array}{l}0.451^{\star \star \star} \\
(0.000)\end{array}$ & \\
\hline DELTA & $\begin{array}{l}0.006^{* *} \\
(0.012)\end{array}$ & $\begin{array}{c}0.005 \\
(0.119)\end{array}$ & $\begin{array}{l}0.006 \\
(0.144)\end{array}$ & & $\begin{array}{l}-0.060^{* * *} \\
(0.000)\end{array}$ & \\
\hline CASH_COMPENSATION & $\begin{array}{l}0.056^{* * *} \\
(0.000)\end{array}$ & $\begin{array}{l}0.056^{\text {** }} \\
(0.000)\end{array}$ & $\begin{array}{l}0.042^{* * *} \\
(0.000)\end{array}$ & & 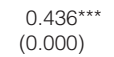 & \\
\hline AGE_40-49 & & $\begin{array}{l}0.049^{\star \star *} \\
(0.000)\end{array}$ & $\begin{array}{c}0.020 \\
(0.111)\end{array}$ & $\begin{array}{c}-0.288 \\
(0.137)\end{array}$ & $\begin{array}{l}-0.462^{\star \star} \\
(0.021)\end{array}$ & $\begin{array}{c}0.102 \\
(0.266)\end{array}$ \\
\hline AGE_50-59 & & $\begin{array}{l}0.067^{\star \star \star} \\
(0.000)\end{array}$ & $\begin{array}{r}0.023^{*} \\
(0.070)\end{array}$ & $\begin{array}{l}-0.519^{\star \star \star} \\
(0.007)\end{array}$ & $\begin{array}{l}-0.625^{\star \star \star} \\
(0.002)\end{array}$ & $\begin{array}{c}0.123 \\
(0.177)\end{array}$ \\
\hline$A G E \geq 60$ & & $\begin{array}{l}0.065^{\text {** }} \\
(0.000)\end{array}$ & $\begin{array}{r}0.026^{*} \\
(0.067)\end{array}$ & $\begin{array}{l}-0.730^{* \star *} \\
(0.000)\end{array}$ & $\begin{array}{l}-0.759^{\star \star \star} \\
(0.000)\end{array}$ & $\begin{array}{l}0.098 \\
(0.285)\end{array}$ \\
\hline In(TENURE) & & $\begin{array}{l}0.009^{\star \star \star} \\
(0.000)\end{array}$ & $\begin{array}{l}0.014^{* * *} \\
(0.000)\end{array}$ & & $\begin{array}{l}-0.420^{\star \star \star} \\
(0.000)\end{array}$ & $\begin{array}{c}-0.008 \\
(0.483)\end{array}$ \\
\hline SIZE & & & $\begin{array}{l}0.042^{\star * *} \\
(0.000)\end{array}$ & $\begin{array}{l}0.419^{\star \star \star} \\
(0.000)\end{array}$ & $\begin{array}{l}0.305^{\star \star \star} \\
(0.000)\end{array}$ & $\begin{array}{l}0.429^{\star \star \star} \\
(0.000)\end{array}$ \\
\hline LEVERAGE & & & $\begin{array}{l}-0.113^{* * *} \\
(0.000)\end{array}$ & & $\begin{array}{r}-0.242^{*} \\
(0.088)\end{array}$ & $\begin{array}{l}-0.147^{\star \star \star} \\
(0.007)\end{array}$ \\
\hline SALES_GROWTH & & & $\begin{array}{l}-0.028^{* * *} \\
(0.002)\end{array}$ & $\begin{array}{l}0.335^{\star \star *} \\
(0.000)\end{array}$ & $\begin{array}{l}0.291^{\star \star \star} \\
(0.001)\end{array}$ & $\begin{array}{l}0.097^{\star \star} \\
(0.036)\end{array}$ \\
\hline ROE & & & $\begin{array}{l}-0.029^{\star \star \star *} \\
(0.000)\end{array}$ & & $\begin{array}{l}-0.279^{\star \star \star} \\
(0.000)\end{array}$ & $\begin{array}{l}0.074^{\star \star \star} \\
(0.000)\end{array}$ \\
\hline MB & & & $\begin{array}{l}0.007^{* *} \\
(0.025)\end{array}$ & & $\begin{array}{l}0.229^{* * \star} \\
(0.000)\end{array}$ & $\begin{array}{l}0.133^{\star \star \star} \\
(0.000)\end{array}$ \\
\hline Fixed effects & None & Industry & $\begin{array}{l}\text { Industry, } \\
\text { Year }\end{array}$ & Industry & $\begin{array}{l}\text { Industry, } \\
\text { Year }\end{array}$ & $\begin{array}{l}\text { Industry, } \\
\text { Year }\end{array}$ \\
\hline $\begin{array}{l}\text { No. of obs. } \\
\text { No. of firms }\end{array}$ & $\begin{array}{r}15,025 \\
2,016\end{array}$ & $\begin{array}{r}14,372 \\
1,997\end{array}$ & $\begin{array}{r}13,897 \\
1,959\end{array}$ & $\begin{array}{r}14,421 \\
1,962\end{array}$ & $\begin{array}{r}13,891 \\
1,957\end{array}$ & $\begin{array}{r}14,068 \\
1,965\end{array}$ \\
\hline$R^{2}$ & $28.77 \%$ & $33.01 \%$ & $36.56 \%$ & $19.93 \%$ & $25.69 \%$ & $40.97 \%$ \\
\hline
\end{tabular}

pensation contract, such as DELTA and CASH_COMPENSATION. In column 2 we add controls for industry fixed effects as well as CEO-specific controls such as AGE and TENURE; the PILOT variable continues to carry a significant positive coefficient. These results suggest that less risk-averse CEOs are associated with higher levels of compensation convexity.

Column 3 of Table 8 reveals that although the coefficient on PILOT remains correctly signed, the significance attenuates when firm-specific controls and year fixed effects are added to the model. There are a variety of explanations for the results in column 3. First, with the notable exception of Graham et al. (2012), the relation between incentives and risk-taking is difficult to observe empirically (Prendergast (2002)). Additionally, recent studies question whether variation in compensation convexity is associated with observable differences in managerial risk-taking (Hayes, Lemmon, and Qiu (2012)). Furthermore, we note that if a CEO's risk aversion is already sufficiently low, then little option-based compensation would be required to counteract risk-related agency costs. 
In a recent survey article, Graham et al. (2012) isolate the most risk-averse CEO respondents in their sample and document a preference for salary versus performance-based pay. Our PILOT proxy isolates the other side of the distribution (i.e., particularly risk-tolerant individuals). In columns 4 and 5 of Table 8, we estimate models testing the relation between compensation structure and our risktaking proxy using a dependent variable motivated by Graham et al. The variable HIGH_PERFORMANCE_PAY takes a value of 1 if the CEO's performance-based compensation (stock, options, and bonus) is in the top tercile of the sample, and 0 otherwise. In column 4, we estimate a model similar to those in Graham et al., and find that the PILOT proxy has significant explanatory power for performancebased pay, controlling for a measure of other CEO equity holdings (DELTA), CEO age, firm size, and industry fixed effects. In column 5, we add several additional controls for other CEO characteristics, firm characteristics, and year fixed effects and continue to find a significantly positive relation between our proxy for risk tolerance and compensation structure. The consistency between these results and those in Graham et al. support the validity of our measure of risk preferences.

Column 6 of Table 8 tests for differences in total compensation. The takeaway point is that the risk-taking proxy is not significantly related to the amount of compensation, only the structure. This indicates that our results are not driven by unobservable CEO ability or a similar omitted factor. Due to the noted relation between our proxy for personal risk tolerance and compensation structure, we control for VEGA in all subsequent tests to isolate the risk-aversion effect from any wealth effect that may be induced by compensation convexity. ${ }^{19}$

\section{F. Robustness}

We interpret our primary findings to indicate that preferences for elevated personal risk-taking among CEOs are associated with greater firm risk, and that one way these CEOs tend to increase the volatility of their firms' equity is by pursuing corporate growth through increased M\&A activity. The results do not appear to be driven by a rural versus urban firm location effect, or by an industry effect. In the Internet Appendix, we also reestimate all models with MSA fixed effects and obtain qualitatively similar results. One difference between our results and those of prior studies is that we fail to document a significant relation between military experience and capital structure or acquisition decisions. There are two possible explanations. First, the prevalence of military CEOs has been declining substantially since the 1980s (Benmelech and Frydman (2015)). Thus, differences in the sample period, and therefore differences in both the frequency and nature of service of the military CEOs in our sample, could plausibly lead to different results. Additionally, our military proxy may be noisier than the one used by Lin, Ma, Officer, and Zou (2011) and Malmendier et al. (2011), which could attenuate the estimated coefficients in these models. Nonetheless, our results are consistent

\footnotetext{
${ }^{19}$ In results reported in the Internet Appendix, we reestimate all models throughout the study controlling for high performance-based pay rather than VEGA and find qualitatively similar results.
} 
with those in Cronqvist et al. (2012), who document similarly weak explanatory power of military experience for capital structure decisions.

One might be concerned that the results are influenced by some industries more than others. The most plausible industry of concern would be the one containing airline-related firms, because these firms may tend to attract CEOs with flying experience. Although it is unlikely that this effect would produce a positive relation between our PILOT variable and firm risk or M\&A activity, it is possible. To address this concern, we purge all airline-related firms from the sample (SIC codes 4512 and 3721) and recalculate all models. The results remain qualitatively similar; thus, our main findings do not appear to be driven by an airline industry effect. General industry dynamics or industry merger waves should be adequately controlled for through the inclusion of industry or firm fixed effects in the models.

A second potential concern with our results is that they merely reflect CEO overconfidence as measured in prior studies. This is unlikely for several reasons. First, both our study and one by Grinblatt and Keloharju (2009) document that overconfidence and sensation seeking are nearly uncorrelated. Moreover, we explicitly control for the overconfidence proxy in reestimations of our models, as reported in the Internet Appendix, and PILOT retains statistical significance. To construct the overconfidence proxy, we follow Hirshleifer, Low, and Teoh (2012) and create a binary variable (CONFIDENT) equal to 1 if the CEO's options exceed $100 \%$ moneyness in the current period or any prior period. The construction is further detailed in the Appendix. Second, as discussed previously, prior finance studies have generally found that overconfident CEOs pursue value-decreasing strategies. However, in the Table 7 results for M\&A announcement returns, we document that, rather, pilot CEOs tend to pursue value-neutral or value-increasing growth opportunities. This finding is inconsistent with an overconfidence trait driving the results. In untabulated tests, we evaluate the equity returns generated by firms with pilot CEOs. ${ }^{20}$ On average, the pilot-CEO firms generate slightly positive, but insignificant, abnormal returns.

A third concern is that the wealth of our sample CEOs differs systematically along the same dimension as the PILOT variable. One argument is that flying is expensive, so only the most successful CEOs will have the resources to become pilots. However, as it turns out, becoming a pilot is not particularly costly; it typically costs less than $\$ 10,000$ for all the training required for a standard private pilot's license. ${ }^{21}$ Furthermore, small planes can often be rented at rates of just a few hundred dollars per day. ${ }^{22}$ Taken together, these costs imply that substantial wealth is not a binding constraint on obtaining an airman certificate. The total compensation values of the pilots and nonpilots in our sample are not significantly

\footnotetext{
${ }^{20}$ Abnormal returns are calculated using the Fama-French (1993) 3-factor model. When the PILOT dummy variable is included as an independent variable, it loads positively with a $p$-value of 0.19. When the 3-factor model is run exclusively on monthly excess returns to pilot firms, it results in alpha of 0.185 with a $p$-value of 0.15 .

${ }^{21}$ See http://www.aopa.org/letsgoflying/faqs.html

${ }^{22}$ See http://www.wingsforrent.com
} 
different, and furthermore, over $99 \%$ of the nonpilots earn in excess of $\$ 200,000$ per year, suggesting that financial constraints are not likely to be a meaningful deterrent in their choice to forego private piloting. A second argument is that some CEOs may pursue riskier corporate strategies in order to increase their wealth due to status concerns (Roussanov and Savor (2014)). However, we find it unlikely that these same CEOs would be more likely to pursue flying as a hobby, as this activity in and of itself does not appear to have a direct impact on individuals' wealth.

\section{Conclusion}

We analyze the effects of a previously unexplored dimension of managerial psychology (personal risk-taking) and document a significant association between it and a variety of corporate policies. Our results demonstrate that CEOs' tolerance for risk in nonpecuniary contexts has explanatory power for corporate project selection and overall firm risk.

CEOs who fly personal aircraft bear elevated health risk. Our results indicate that pilot CEOs accept more sensitivity to risk in their compensation contracts, but also that they are associated with higher levels of firm risk beyond the amount explained by any wealth effect. These results are consistent with behavioral consistency in risk preferences.

A large literature examines the agency costs that are borne by shareholders when risk-averse managers bypass risky but positive-NPV projects. Corporate acquisitions represent project selection choices, and we find that pilot CEOs engage in elevated levels of acquisition activity. Furthermore, within the subset of firms with few organic investment opportunities, where the selection of high-risk high-reward projects could likely be easily avoided, we find that the acquisition activity of pilot CEOs leads to significantly positive value creation. Overall, our results suggest that $\mathrm{CEO}$ risk aversion contains meaningful variation of economic relevance to shareholders, beyond that which is influenced directly by shareholders through compensation structure.

One important policy implication is that unlike an overconfidence measure based on option holding behavior, which reveals itself only many years after a chief executive is hired, personal risk-taking is often observable ex ante to the CEO's tenure. Although flying airplanes may be relatively rare, there are a variety of other activities that could plausibly be categorized as elevating exposure to health risk and may lead to similar outcomes.

Finally, several recent studies examine biologically based variation in risk tolerance (e.g., Cronqvist and Siegel (2015), Barnea, Cronqvist, and Siegel (2010), Sapienza, Zingales, and Maestripieri (2009), and Cesarini, Johannesson, Lichtenstein, Sandewall, and Wallace (2010)). A promising area for future research will be to better understand the myriad behavioral characteristics, both experiential and biological, that lie behind differential preferences for risk-taking, and the contexts in which increased risk-taking is likely to add shareholder value. Shedding light on these traits and the corporate policies associated with them will ultimately lead to better corporate decision making. 


\section{Appendix. Variable Definitions}

CEO Characteristics

PILOT: Equal to 1 if CEO has had at least one certificate in FAA records, and 0 otherwise. Source: Federal Aviation Administration.

VEGA: Dollar change in portfolio value for a 0.01 change in the annualized standard deviation of stock returns (Core and Guay (2002)). Source: Compustat ExecuComp.

HIGH_PERFORMANCE_PAY: Equal to 1 if (TDC1 - SALARY)/TDC1 in Compustat database falls in the top tercile of the sample. Source: Compustat ExecuComp.

DELTA: Dollar change in portfolio value for a 1\% change in the stock price (Core and Guay (2002)). Source: Compustat ExecuComp.

CASH_COMPENSATION: (SALARY + BONUS) in Compustat database. Source: Compustat ExecuComp.

TOTAL_COMPENSATION: TDC1 in Compustat database. Source: Compustat ExecuComp.

MILITARY: Equal to 1 if CEO has military experience, and 0 otherwise; coded using BoardEx biographical information.

CONFIDENT: Following Hirshleifer et al. (2012), equal to 1 if the CEO's options exceed $100 \%$ moneyness in the current period or any prior period. Moneyness is defined by ExecuComp as [PRCC_F - (OPT_UNEX_EXER_EST_VAL/OPT_UNEX_EXER_ NUM)]/[OPT_UNEX_EXER_EST_VAL/OPT_UNEX_EXER_NUM].

DEPRESSION: Equal to 1 if CEO born between 1920 and 1929, and 0 otherwise.

AGE: CEO's age, updated annually. Source: Compustat ExecuComp.

TENURE: Years of service as CEO at given firm. Source: Compustat ExecuComp.

Firm Characteristics (Source: Compustat)

ASSETS: AT in Compustat database.

ASSET_TANGIBILITY: PPENT/AT in Compustat database.

CAPEX: CAPX in Compustat database.

DIVIDEND_YIELD: DVPSP_F/PRCC_F in Compustat database.

FIRM_AGE: Cumulative number of firm-years listed in Compustat database.

FREE_CASH_FLOW: (OIBDP - XINT - TXT - CAPX)/AT ${ }_{t-1}$ in Compustat database.

LEVERAGE: (DLC + DLTT)/AT in Compustat database.

LOSS_DUMMY: Equal to 1 if negative net income (NI) in given year, and 0 otherwise.

MB: (PRCC_F $\times$ CSHO)/SEQ in Compustat database.

$\mathrm{Q}: \quad\left[\mathrm{AT}-\mathrm{SEQ}+\left(\mathrm{PRCC} \_\mathrm{F} \times \mathrm{CSHO}\right)\right] / \mathrm{AT}$ in Compustat database.

R\&D: XRD/AT in Compustat database.

ROE: EBITDA / $/ \mathrm{AT}_{t-1}$ in Compustat database.

SALES_GROWTH: $\quad$ REVT/REVT $_{t-1}$ in Compustat database.

Merger Characteristics (Source: Thomson Reuters SDC Platinum)

CASH PAYMENT: Equal to 1 if transaction consideration is cash, and 0 otherwise.

DIVERSIFYING: Equal to 1 if bidder and target in different 3-digit SIC codes, and 0 otherwise.

PRIVATE_TARGET: $\quad$ Equal to 1 if target private, and 0 otherwise.

TRANS_VALUE: Transaction value in \$millions.

\section{References}

Amihud, Y., and B. Lev. "Risk Reduction as a Managerial Motive for Conglomerate Mergers." Bell Journal of Economics, 12 (1981), 605-617.

Barnea, A.; H. Cronqvist; and S. Siegel. "Nature or Nurture: What Determines Investor Behavior?" Journal of Financial Economics, 98 (2010), 583-604.

Bauguess, S., and M. Stegemoller. "Protective Governance Choices and the Value of Acquisition Activity." Journal of Corporate Finance, 14 (2008), 550-566.

Benmelech, E., and C. Frydman. "Military CEOs." Journal of Financial Economics, 117 (2015), 43-59.

Cesarini, D.; M. Johannesson; P. Lichtenstein; Ö. Sandewall; and B. Wallace. "Genetic Variation in Financial Decision-Making." Journal of Finance, 65 (2010), 1725-1754. 
Chava, S., and A. Purnanandam. "CEOs versus CFOs: Incentives and Corporate Policies.” Journal of Financial Economics, 97 (2010), 263-278.

Chyz, J. "Personally Tax Aggressive Executives and Corporate Tax Sheltering." Journal of Accounting and Economics, 56 (2013), 311-328.

Coles, J. L.; N. D. Daniel; and L. Naveen. "Managerial Incentives and Risk-Taking." Journal of Financial Economics, 79 (2006), 431-468.

Core, J., and W. Guay. "Estimating the Value of Employee Stock Option Portfolios and Their Sensitivities to Price and Volatility." Journal of Accounting Research, 40 (2002), 613-630.

Cronqvist, H.; A. K. Makhija; and S. E. Yonker. "Behavioral Consistency in Corporate Finance: CEO Personal and Corporate Leverage.” Journal of Financial Economics, 103 (2012), 20-40.

Cronqvist, H., and S. Siegel. "The Origins of Savings Behavior." Journal of Political Economy, 123 (2015), 123-169.

Fama, E. F., and K. R. French. "Common Risk Factors in the Returns on Stocks and Bonds." Journal of Financial Economics, 33 (1993), 3-56.

Graham, J. R.; C. R. Harvey; and M. Puri. "Capital Allocation and Delegation of Decision-Making Authority within Firms.” Journal of Financial Economics, 115 (2015), 449-470.

Graham, J. R.; C. R. Harvey; and M. Puri. "Managerial Attitudes and Corporate Actions." Journal of Financial Economics, 109 (2012), 103-121.

Grinblatt, M., and M. Keloharju. "Sensation Seeking, Overconfidence, and Trading Activity." Journal of Finance, 64 (2009), 549-578.

Guay, W. R. "The Sensitivity of CEO Wealth to Equity Risk: An Analysis of the Magnitude and Determinants." Journal of Financial Economics, 53 (1999), 43-71.

Harford, J.; M. L. Humphery-Jenner; and R. Powell. "The Sources of Value Destruction in Acquisitions by Entrenched Managers.” Journal of Financial Economics, 106 (2012), 247-261.

Harford, J., and K. Li. "Decoupling CEO Wealth and Firm Performance: The Case of Acquiring CEOs." Journal of Finance, 62 (2007), 917-949.

Hayes, R. M.; M. Lemmon; and M. Qiu. "Stock Options and Managerial Incentives for Risk Taking: Evidence from FAS 123R.” Journal of Financial Economics, 105 (2012), 174-190.

Hirshleifer, D.; A. Low; and S. H. Teoh. "Are Overconfident CEOs Better Innovators?" Journal of Finance, 67 (2012), 1457-1498.

Lin, C.; Y. Ma; M. Officer; and H. Zou. "CEOs' Military Experience and Acquisition Decisions." Working Paper, Chinese University of Hong Kong, Lingnan University, and Loyola Marymount University (2011).

Low, A. "Managerial Risk-Taking Behavior and Equity-Based Compensation." Journal of Financial Economics, 92 (2009), 470-490.

Malmendier, U., and G. A. Tate. "Who Makes Acquisitions? CEO Overconfidence and the Market's Reaction.” Journal of Financial Economics, 89 (2008), 20-43.

Malmendier, U.; G. A. Tate; and J. Yan. "Overconfidence and Early-Life Experiences: The Effect of Managerial Traits on Corporate Financial Policies.” Journal of Finance, 66 (2011), 1687-1733.

McFall, M. C. "Lincoln National Aviation Mortality and Claim Analysis." North American Actuarial Journal, 33 (1992), 6-8.

Moeller, S. B.; F. P. Schlingemann; and R. M. Stulz. "Firm Size and the Gains from Acquisitions." Journal of Financial Economics, 73 (2004), 201-228.

Pratt, J. W. "Risk Aversion in the Small and in the Large.” Econometrica, 32 (1964), 122-136.

Prendergast, C. "The Tenuous Trade-Off Between Risk and Incentives.” Journal of Political Economy, 110 (2002), 1071-1102.

Rajan, R. G., and L. Zingales. "What Do We Know about Capital Structure? Some Evidence from International Data." Journal of Finance, 50 (1995), 1421-1460.

Rau, P. R., and T. Vermaelen. "Glamour, Value and the Post-Acquisition Performance of Acquiring Firms.” Journal of Financial Economics, 49 (1998), 223-253.

Roussanov, N., and P. Savor. "Marriage and Managers' Attitudes to Risk." Management Science, 60 (2014), 2496-2508.

Sapienza, P.; L. Zingales, and D. Maestripieri. "Gender Differences in Financial Risk Aversion and Career Choices Are Affected by Testosterone." Proceeding of the National Academy of Sciences, 106 (2009), 15268-15273.

Smith, C. W., Jr., and R. Stulz. "The Determinants of Firms' Hedging Policies.” Journal of Financial and Quantitative Analysis, 20 (1985), 391-405.

Yermack, D. "Flights of Fancy: Corporate Jets, CEO Perquisites, and Inferior Shareholder Returns." Journal of Financial Economics, 80 (2006), 211-242.

Zuckerman, M. "Dimensions of Sensation Seeking." Journal of Consulting and Clinical Psychology, 36 (1971), 45-52.

Zuckerman, M. Sensation Seeking and Risky Behavior. Washington, DC: American Psychological Association (2007). 